\title{
Review on Dynamic Recrystallization of Martensitic Stainless Steels during Hot Deformation: Part I-Experimental Study
}

\author{
Hamed Aghajani Derazkola ${ }^{1, * \mathbb{C}}$, Eduardo García Gil ${ }^{1}{ }^{\mathbb{D}}$, Alberto Murillo-Marrodán $^{1} \mathbb{D}$ and Damien Méresse ${ }^{2}$ \\ 1 Department of Mechanics, Design and Industrial Management, University of Deusto, 48007 Bilbao, Spain; \\ e.garcia@deusto.es (E.G.G.); alberto.murillo@deusto.es (A.M.-M.) \\ 2 LAMIH UMR CNRS 8201, Université Polytechnique Hauts-de-France, CEDEX 9, \\ F-59313 Valenciennes, France; dmeresse@uphf.fr \\ * Correspondence: h.aghajani@deusto.es
}

Citation: Derazkola, H.A.; García Gil, E.; Murillo-Marrodán, A.; Méresse, D. Review on Dynamic Recrystallization of Martensitic Stainless Steels during Hot Deformation: Part I-Experimental Study. Metals 2021, 11, 572. https:// doi.org/10.3390/met11040572

Academic Editor: Stefano Spigarelli

Received: 22 February 2021

Accepted: 25 March 2021

Published: 1 April 2021

Publisher's Note: MDPI stays neutral with regard to jurisdictional claims in published maps and institutional affiliations.

Copyright: (c) 2021 by the authors. Licensee MDPI, Basel, Switzerland. This article is an open access article distributed under the terms and conditions of the Creative Commons Attribution (CC BY) license (https:// creativecommons.org/licenses/by/ $4.0 /)$.

\begin{abstract}
The evolution of the microstructure changes during hot deformation of high-chromium content of stainless steels (martensitic stainless steels) is reviewed. The microstructural changes taking place under high-temperature conditions and the associated mechanical behaviors are presented. During the continuous dynamic recrystallization (cDRX), the new grains nucleate and growth in materials with high stacking fault energies (SFE). On the other hand, new ultrafine grains could be produced in stainless steel material irrespective of the SFE employing high deformation and temperatures. The gradual transformation results from the dislocation of sub-boundaries created at low strains into ultrafine grains with high angle boundaries at large strains. There is limited information about flow stress and monitoring microstructure changes during the hot forming of martensitic stainless steels. For this reason, continuous dynamic recrystallization (cDRX) is still not entirely understood for these types of metals. Recent studies of the deformation behavior of martensitic stainless steels under thermomechanical conditions investigated the relationship between the microstructural changes and mechanical properties. In this review, grain formation under thermomechanical conditions and dynamic recrystallization behavior of this type of steel during the deformation phase is discussed.
\end{abstract}

Keywords: martensitic stainless steels; microstructure changes; hot deformation

\section{Introduction}

Martensitic stainless steels (MSS) are a family of alloys composed mainly of iron, chromium (Cr), and carbon (c) as main elements [1]. MSS have a martensitic crystal structure in the hardened condition [2]. They are ferromagnetic, treatable and have better corrosion resistance comparing to other types of stainless steels (SS). Chromium (Cr) in these steels is usually $10.5-18 \%$ weight percentage (wt \%) with a higher percentage of carbon $(C)$ in comparison to ferritic steels [3-5]. The specific amount of $C$ and $C r$ is used to ensure the formation of a martensitic structure after a complete cycle of heat treatment [6]. In MSS, an adequate $\mathrm{Cr}$ amount is needed to provide corrosion resistance, which is achieved by the formation of a chromium oxide film on the surface $[7,8]$. The steel requires at least 11 wt \% Cr to have stainless characteristics. On the other hand, the austenite phase cannot be stable in steels with more than $10.5 \% \mathrm{Cr}$. For this reason, carbon, nitrogen, nickel, and manganese are added to MSS as austenite stabilizers. In addition, some other elements like molybdenum (Mo) and tungsten (W) are added to carbide for strengthening the MSS [9]. In such cases, $\mathrm{Mo}_{2} \mathrm{C}$ and $\mathrm{W}_{2} \mathrm{C}$ can improve the strength of MSS. Elements such as titanium and aluminum are added to the low carbon MSS to promote the precipitation of intermetallics (IMC), such as NiTi and NiAl [10].

In addition, the high carbon content favors the formation of some carbides with other elements like niobium, silicon, tungsten, and vanadium, which increase the wear resistance of MSS. In some cases, small amounts of nickel are added to MSS to improve corrosion 
resistance and toughness [9]. During MSS production, the temperatures in the furnace are high enough to transform the steel structure into austenite. After cooling treatment in air, the microstructure of MSS will transform allotropically into the martensite phase [11]. With different heat treatments, such as quenching and tempering, it is possible to achieve a wide range of strength (between 275-1900 MPa), wear and corrosion resistance [12]. In 1913, Harry Brearley invented the first class of MSS that called 410 grades. The 410 is the primary grade of MSS commercialized and standardized in the 1930s and 1940s [13]. MSS are used in various applications like surgical instruments, springs, valves, shafts, bearings, turbine blades, and petrochemical tools [14]. The 410 stainless steel (SS) has evolved through the years by adding chemical elements to enhance its use in specific applications [15]. Figure 1 illustrates a schematic view of MSS grades with additional elements compared with 410.

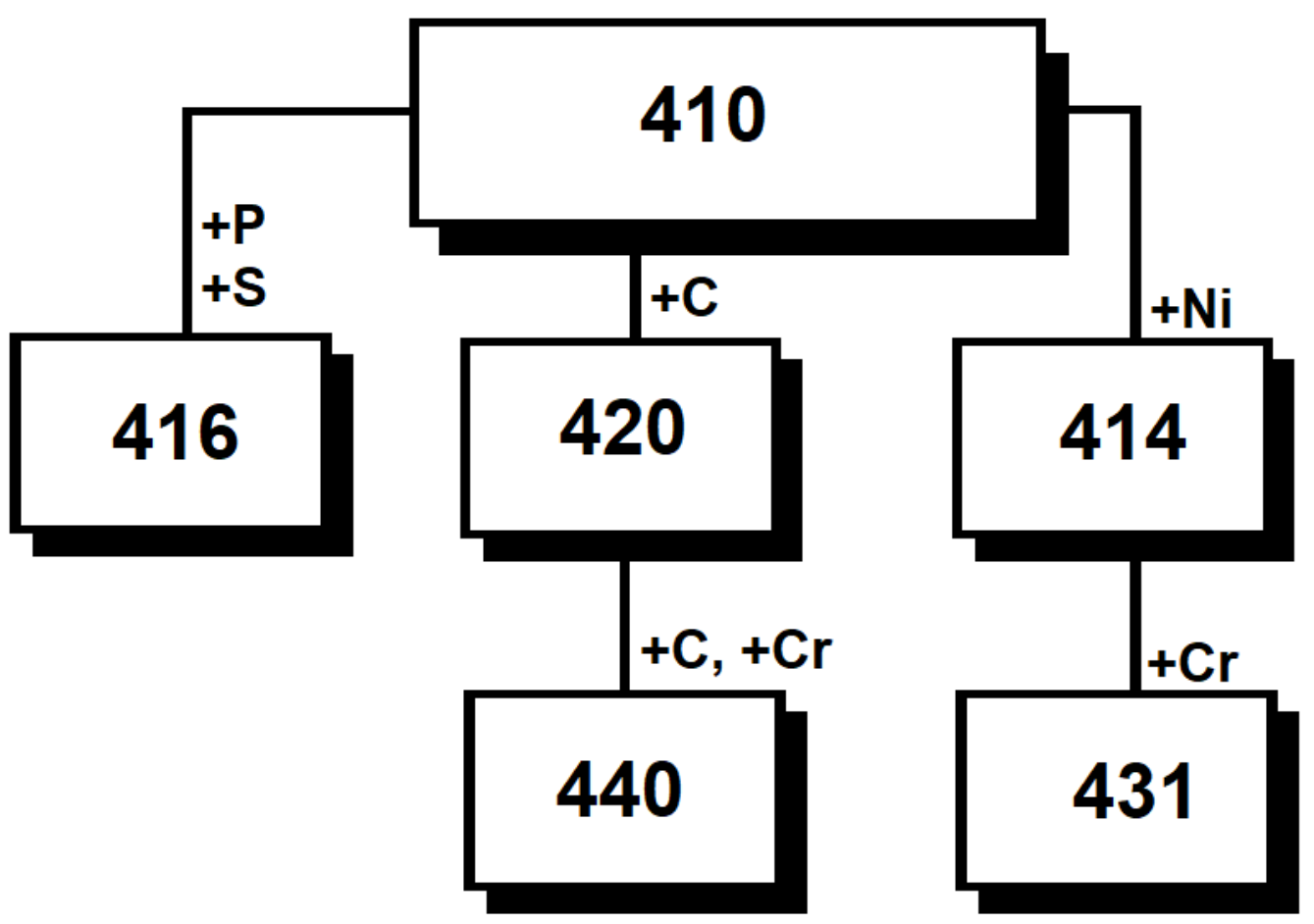

Figure 1. Development of other grades of martensitic stainless steels (MSS) from the 410 [11].

In addition, the chemical composition of carbide strengthened MSS is presented in Table 1. The steels in Table 1 are divided into three groups. The first group is the low to medium C $(0.10 \pm 0.30 \mathrm{wt} \%)$ alloys with approximately $12 \mathrm{wt} \%$ of $\mathrm{Cr}$. They are used in creep resistance applications and also in steel components that require ductile fracture resistance at high temperatures. The second group is those containing higher levels of $C$ $(0.60-1.2 \mathrm{wt} \%)$ and rather large amounts of $\mathrm{Cr}(16-18 \mathrm{wt} \%)$. Higher content of $\mathrm{C}$ and $\mathrm{Cr}$ is added in this group to achieve higher hardness and promotion of wear resistance. The third group is the high chromium cold work die steels (D2 and D7). The high Cr content and cold working on these steels improve wear and corrosion resistance simultaneously. As mentioned before, the MSS is usually used in components where corrosion and oxidation resistance with high strength are required [16]. From a metallurgical point of view, three types of MSS exist, and their behavior as traditional (first and second types), new or uncategorized (third type) MSS could be studied [17]. The first type contains specific wt $\%$ carbon (as reported in Table 1) and is strengthened by iron carbide precipitation when tempered at low temperatures or by alloy carbide precipitation when tempered at higher temperatures (secondary hardening), as discussed before. The second type contains a lower amount of carbon and is strengthened by the precipitation of particles of copper or intermetallic on tempering [18]. Another type is the precipitation-strengthen MSS. Precipitation strengthened MSS are low-C steels, strengthened by the precipitation of 
second-phase particles, other than alloy carbides, during thermal treatment. Pure copper particles, $\mathrm{NiAl}, \mathrm{NiTi}, \mathrm{Ni}_{3} \mathrm{Ti}$ and $\mathrm{Ni}_{3} \mathrm{Be}$, are well-known precipitates in this MSS type [18]. Table 2 presents some grades of precipitation strengthened MSS.

Table 1. Chemical composition of various grades of MSS.

\begin{tabular}{cccccccccccc}
\hline Grade & C & Mn & Si & Cr & Mo & W & P & V & S & Ref. \\
\hline 410 & 0.15 & 1.0 & 0.5 & $11.5-13$ & - & - & 0.04 & - & 0.03 & {$[19]$} \\
416 & 0.15 & 1.25 & 1.0 & $12.0-14.0$ & 0.6 & - & 0.04 & - & 0.15 & {$[20]$} & - \\
420 & $0.15-0.4$ & 1.0 & 1.0 & $12.0-14.0$ & - & - & 0.04 & 0.03 & {$[21,22]$} \\
422 & 0.23 & 1.0 & 0.75 & 12.0 & 1.0 & 1.0 & 0.04 & 0.22 & - & {$[23]$} \\
431 & 0.2 & 1.0 & 1.0 & $15.0-17.0$ & $1.25-2.00$ & - & 0.04 & - & 0.03 & {$[24]$} \\
$440 \mathrm{~A}$ & $0.60-0.75$ & 1.0 & 1.0 & $16.0-18.0$ & 0.75 & - & 0.04 & - & 0.03 & {$[25]$} \\
$440 \mathrm{~B}$ & $0.75-0.95$ & 1.0 & 1.0 & $16.0-18.0$ & 0.75 & - & 0.04 & - & 0.03 \\
$440 \mathrm{C}$ & $0.95-1.20$ & 1.0 & 1.0 & $16.0-18.0$ & 0.75 & - & 0.04 & - & 0.03 & {$[26]$} \\
D2 & 1.50 & 0.3 & 0.25 & 12 & 1.0 & - & - & 1.0 & - & {$[28]$} \\
D7 & 2.35 & 0.4 & 0.4 & 12 & 1.0 & - & - & 4.0 & - & {$[29]$} \\
8Cr13MoV & 0.775 & 0.458 & 0.333 & 14.68 & 0.213 & - & 0.031 & 0.182 & 0.004 & {$[30]$} \\
\hline
\end{tabular}

Table 2. Chemical composition of precipitation MSS grades.

\begin{tabular}{|c|c|c|c|c|c|c|c|c|c|c|}
\hline Grade & $\mathrm{C}$ & Co & $\mathrm{Cu}$ & $\mathrm{Cr}$ & Si & Mo & $\mathbf{N i}$ & Al & other & Ref. \\
\hline PH15-5 & 0.04 & - & 3.0 & 15 & - & - & 4.7 & - & $0.20 \mathrm{Nb}$ & {$[29,31]$} \\
\hline PH7-17 & 0.04 & - & - & 17.06 & 0.385 & - & 7.2 & 1.06 & $0.674 \mathrm{Mn}$ & [32] \\
\hline Custom 450 & 0.04 & - & 1.5 & 11.5 & - & - & 8.5 & - & $0.7 \mathrm{Nb}$ & [33] \\
\hline PH17-4 & 0.07 & - & 3.5 & 16.5 & - & - & 4.0 & - & $0.3 \mathrm{Nb}+\mathrm{Ta}$ & {$[34,35]$} \\
\hline PH13-8 & 0.03 & - & - & 12.6 & - & 1.7 & 7.9 & 1.0 & - & [36] \\
\hline Custom 465 & 0.02 & - & - & 11.8 & - & 1.0 & 11.0 & - & 1.7 & [37] \\
\hline Custom 455 & 0.05 & - & 2.0 & 11.5 & - & 0.5 & 8.5 & - & 1.1 & [38] \\
\hline SM2Mo & 0.02 & - & - & 12.59 & 0.42 & 1.90 & 5.01 & & 0.0062 & {$[36,39,40]$} \\
\hline $\mathrm{SM} 2 \mathrm{MoNb}$ & 0.022 & - & - & 12.91 & 0.41 & 2.05 & 5.16 & & 0.0043 & [41-43] \\
\hline Pyromet X-15 & 0.01 & 20 & - & 15 & - & 2.9 & - & - & - & [11] \\
\hline Pyromet X-23 & 0.03 & 10 & - & 10 & - & 5.5 & 7.0 & - & - & [11] \\
\hline $2 \mathrm{Cr} 13$ & 0.18 & - & - & 12.86 & 0.39 & - & 0.12 & - & $0.53 \mathrm{Mn}+0.002 \mathrm{~S}$ & [44] \\
\hline 00Cr13Ni5Mo2 & 0.013 & - & - & 12.97 & 0.18 & 2.04 & 4.92 & - & $0.59 \mathrm{Mn}+0.001 \mathrm{~S}$ & [44] \\
\hline $18 \mathrm{Cr}-5 \mathrm{Ni}-4 \mathrm{Cu}-\mathrm{N}$ & 0.06 & - & 4.13 & 17.63 & 0.86 & 2.11 & 5.55 & - & $0.08 \mathrm{Nb}+0.13 \mathrm{~V}+0.41 \mathrm{~N}+0.025 \mathrm{P}$ & {$[45]$} \\
\hline
\end{tabular}

The third type corresponds to those MSS, which are strengthened by the precipitation of both alloy carbides and intermetallic. The chemical composition of this group (3rd type) involves the combined precipitation of $\mathrm{NiAl}$ and alloy carbides (secondary hardening). This type has standard high chromium content and alloying combinations that allow quenching from the austenitizing temperature to obtain an almost completely martensitic structure with a small amount of retained austenite [18]. Table 3 presents the chemical composition of 3rd group samples.

Table 3. Chemical composition of intermetallic-carbide-strengthened MSS grades.

\begin{tabular}{ccccccccc}
\hline Grade & C & Cr & Ni & Mo & Co & V & Nb & Ref. \\
\hline AFC77 & 0.15 & 14.5 & - & 5 & 13.5 & - & - & {$[46]$} \\
\hline AFC260 & 0.08 & 15.5 & 2.0 & 4.3 & 13.0 & - & - & {$[13]$} \\
\hline HSL 180 & 0.20 & 12.5 & 1.0 & 2.0 & 15.5 & - & - & {$[11]$} \\
\hline CSS-42L & 0.13 & 13.8 & 2.1 & 4.7 & 12.5 & 0.60 & 0.04 & {$[11]$} \\
\hline
\end{tabular}

Metal forming (metalworking) consists of deformation processes in which a metal billet or blank is shaped by the action of tools or dies. The design and control of such processes or final products depend on the base material's characteristics, the conditions 
at the tool/workpiece interface, the mechanics of plastic deformation (metal flow), the equipment used, and the finished product requirements [47]. Among various metals and alloys, stainless steel is favorable for industries due to its excellent properties and reasonable price. Hot metalworking is one of the major technologies used to produce stainless steel products. In this process, the stainless steel as raw material is in billet, rod, or slab form, and the surface-to-volume ratio in the formed part increases considerably under the action of primarily compressive loading [48,49]. Rolling, skew mills, ring rolling, forging, draw benches for tube and rod, and extrusion are samples of manufacturing processes that form stainless steels in hot condition. Among metallurgical changes of metallic materials, dynamic recrystallization (DRX) is very crucial to the microstructural evolution during hot deformation of alloys with low, medium, and high stacking fault energy (SFE) [50,51]. This phenomenon changes the microstructure substantially through nucleation and growth of new strain-free grains at the expense of pre-existing ones [52,53]. The DRX is of critical importance from the industrial viewpoint because it reduces the stored strain energy, and the corresponding softening effect decreases the required force to shape a workpiece. Taking advantage of DRX to decrease the required energy for shaping a product and avoiding plastic instabilities or premature fracture is quite a practical way in different industrial manufacturing processes [6]. In addition to this, DRX often contributes to improving microstructure, thereby refining the grain structure and improving the final product's mechanical properties. For a careful design of the hot working process, having in-depth information about a material's dynamic recrystallization behavior is essential [54]. There is sufficient literature about DRX phenomena in stainless steel during hot forming, but there is not comprehensive literature or review about DRX in martensitic stainless steels during how working. Based on the mentioned underlying phenomena, this review article's aim is a deep understanding of DRX in MSS from an experimental point of view.

\section{Hot Formability of MSS}

Generally, hot working refers to the temperature of mechanical processing that is above half of the melting temperature (Tm) of base metal. Being above $0.5 \mathrm{Tm}$ decreases yield strength and hardness and increases the ductility of metallic materials [55]. From a metallurgical point of view, the plastic deformation above the metal's recrystallization temperature is called hot working (forming) [56].

From the manufacturing processes point of view, metal forming is divided into two main groups: sheet metal forming and bulk metal forming. One of the main parameters to find specific material that the specific process can form is workability or formability test. There are several kinds of formability tests in sheet metal forming. Uniaxial and multiaxial tensile tests in various temperatures are a well-known approach to find the formability of sheet metals. The formability limitation, mechanical properties, and prediction of fracture during sheet metal forming are accessible by formability test results.

On the other hand, in bulk metal forming, like forging, extrusion, coining, rolling, and stretching, another type of workability test is implemented-this type of test is called a hot compression test. The dimension of raw materials and applied stress concept informing process are the main results that caused researchers to use hot compression test in the laboratory. The compression stress for the flow of materials is the primary stress used in bulk metals forming like hydrostatic forging, orbital forging, skew rolling, tube forming, extrusion, and even solid-state additive manufacturing hot conditions. Some research has been done to develop new workability tests for materials in bulk scale, but so far, the primary test for formability (workability) of metallic materials, especially steel, is the hot compression test.

Various forming processes of metals, like forging, rolling, drawing, and extrusion, can be done in hot conditions [57]. In order to understand the behavior in hot conditions of metallic materials, such as MSS, hot compression tests are usually carried out to characterize hot workability (formability). This test consists of isothermal tests in a wide range of temperature and strain rates. This experiment is pervasive and well-known in laboratories 
and industry [58]. The sample is heated up to the desired temperature (near the actual temperature of considered hot forming). It remains at the temperature for a specific period, and after this, the compression test is carried out on the sample while the high temperature is maintained. At the final stage, the piece is quenched to ambient temperature as a real situation in the industry [59].

The temperature, duration time of heating, and heat treatment could vary depending on both the chemical composition of the steel and the forming process (various strain rates) studied. For the test, a cylindrical specimen with a specific section and height is machined from the as-received bar. First, the sample is heated using a constant heating rate until the highest temperature of the test campaign is reached. This temperature is then maintained for a certain time to ensure homogeneity and, after this period, it is cooled down to the test temperature. Then the isothermal compression test is carried out at various temperatures and strain rates. There are standards for testing procedures like ASTM-E209 (standard practice for compression tests of metallic materials) that can be used [60]. The result is the flow stress behavior of the material under different plastic deformation conditions. Figure 2 shows an example of a hot compression test setup that was employed for various MSS. As seen, the heating rate, heating period, and deformation time (strain rate) are different.

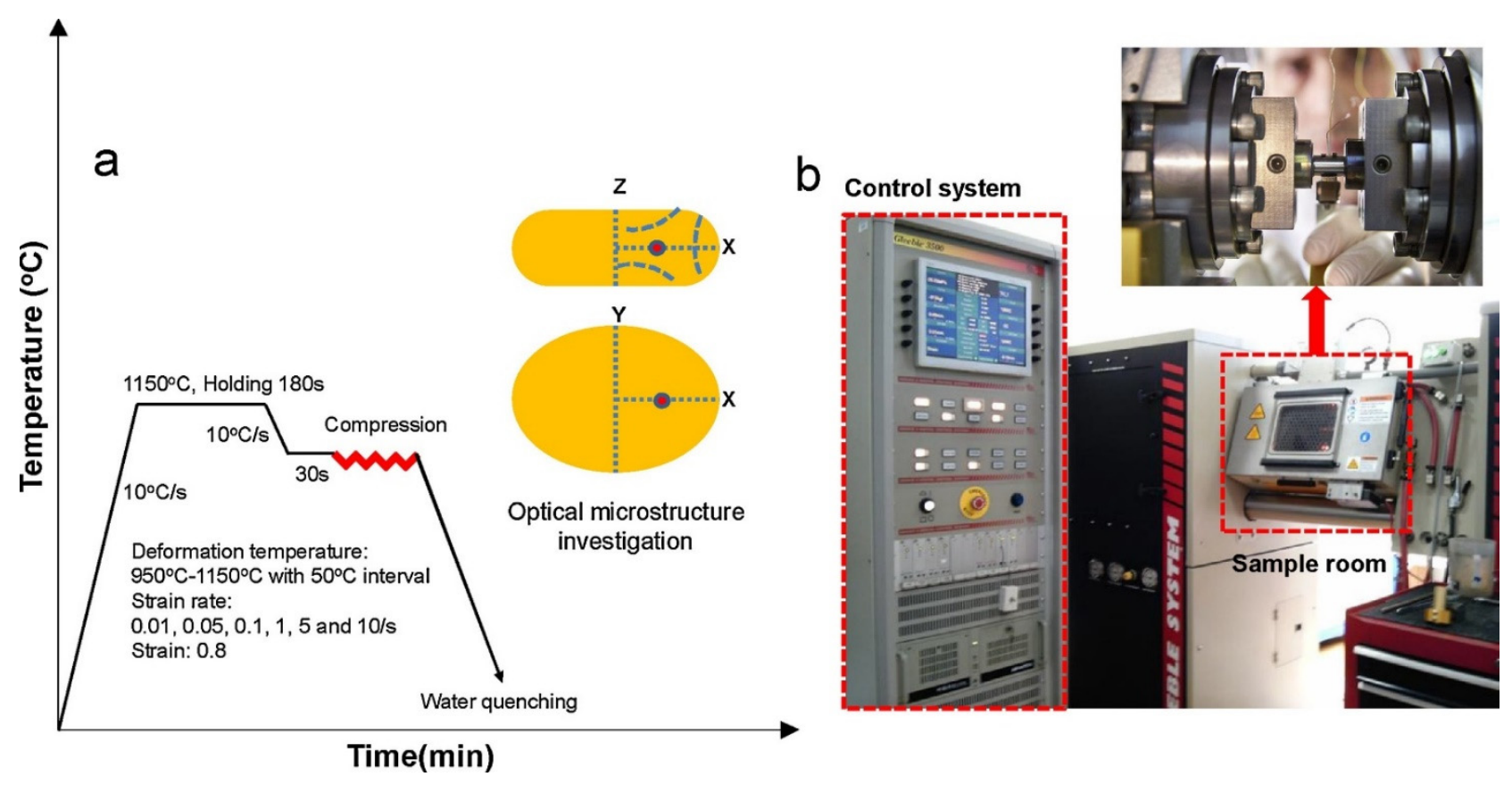

Figure 2. (a) Schematic representation of hot compression test and (b) illustration of the testing machine [61].

\section{Dynamic Recrystallization of MSS under Hot Deformation}

The word recrystallization usually refers to the replacement of a deformation microstructure by new grains [62,63]. The process of recrystallization during heat treatment is called static recrystallization (SRX) [64,65]. SRX (primary recrystallization) is one of the most studied phenomena, which refers to the nucleation and growth of new grains during heat treatment $[40,66]$. The schematic view of this process is depicted in Figure 3. 
Cold working

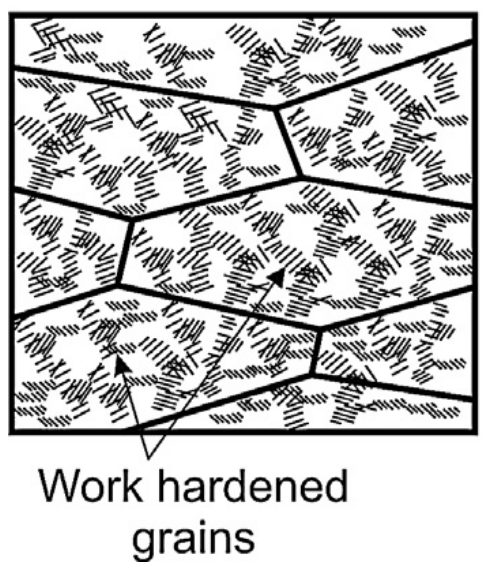

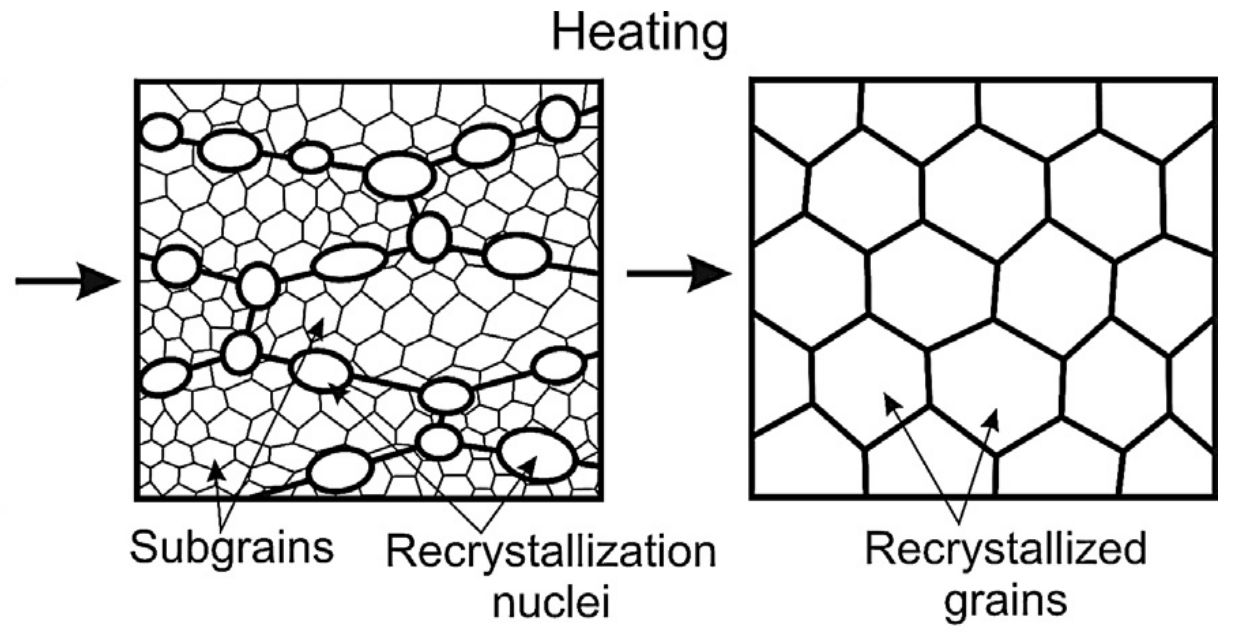

Figure 3. Schematic representation of the discontinuous static recrystallization (dSRX) taking place during the annealing of strain hardened materials [67].

During the early stages of heat treatment, static recovery (SRV) develops recrystallization nuclei as fine dislocation-free crystallites. In the early stages of heat treatment, the development of recrystallization nuclei development is started. In this stage, the recrystallization nuclei are fine dislocation-free crystallites. The nuclei grow by the distant migration of the boundaries, which consume the strain-hardened microstructure. In the early-stages of SRX, the nuclei are outlined by low angle boundaries (LAGBs), the misorientations, of which gradually increase until they attain values typical of high angle boundaries (HABs) $[68,69]$. During heat treatment, the microstructure is a mixture of recrystallized and strain hardened grains. This type of microstructure is known as discontinuous static recrystallization (dSRX) [70]. Alongside, the sub-boundary misorientation $(\theta)$ increases gradually till all the low-angle boundaries (LABs) are transformed into HABs, and this type of microstructure remains homogeneous all over. This structure is referred to as in situ or continuous static recrystallization (cSRX). SRX occurs to strain hardened metals heated above approximately half of their melting point $(\sim 0.5 \mathrm{Tm})$. During hot forming processes, the material is heated up before the process, and after its deformation, it tolerates another thermal cycle as heat treatment. For this reason, a billet could have partial SRX in its microstructure before starting the hot process [70].

At high strains and temperatures above about $0.5 \mathrm{Tm}$ (as a hot deformation requirement), the new grains appear at the nucleation strain and then completely replace the initial microstructure. This mechanism is called dynamic recrystallization (DRX). DRX phenomena are acknowledged as an important feature to restore the ductility of those materials, which are being work hardened during the deformation process. DRX allows large deformation in the material without crack or damage appearance [71,72].

Typically, DRX is favored by high temperatures and low strain rates and is also acknowledged as a grain refinement mechanism under most forming conditions. A new grain structure appears after DRX by the formation and migration of high-angle grain boundaries, promoting the grain refinement of the deformed alloy $[67,68]$. The DRX has three main subgroups that consist of discontinuous dynamic recrystallization (dDRX), continuous dynamic recrystallization (cDRX) and geometric dynamic recrystallization (gDRX) [54,73-76]. The dDRX has two main phases, namely, nucleation and growth stages [77]. The dDRX occurs by means of bulging mechanisms. Increasing deformation leads to fluctuations in the grain boundary, leading to the formation of serrations and bulges that eventually transform into new strain-free grains [78-80]. It consists of grain bulging, dislocation rearrangement, and boundary movement [81].

During plastic deformation, the dislocations glide and climb to form sub-grains by dynamic recovery (DRV) [82]. Dislocation motions prepare new grains nucleation. In 
this phase, the bulges without or with a few dislocations are surrounded by accumulated dislocations. After that, the bulges separate to generate nuclei in the early stages of dDRX [83]. Nuclei are high-energy sites that pin the movement of the dislocations. In the final stages of deformation, the nuclei grow until original grains are replaced by finer recrystallized grains. There is a slow transformation of the sub-grains mainly formed in the vicinity of the boundaries into nuclei delineated by HABs and referred to as discontinuous dynamic recrystallization (dDRX) [84]. The dDRX is rarely reported in high chromium MSS during hot deformation. This type of recrystallization (dDRX) is common in low and medium stacking-fault energy (SFE) steels, and MSS are in the category of high SFE materials [85]. The schematic view of dDRX is depicted in Figure 4.

(1) Original Coarse Grain

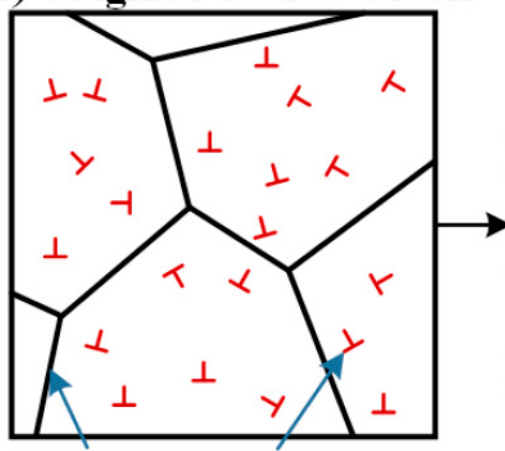

HAGB Dislocation

(4) Nuclei Growth

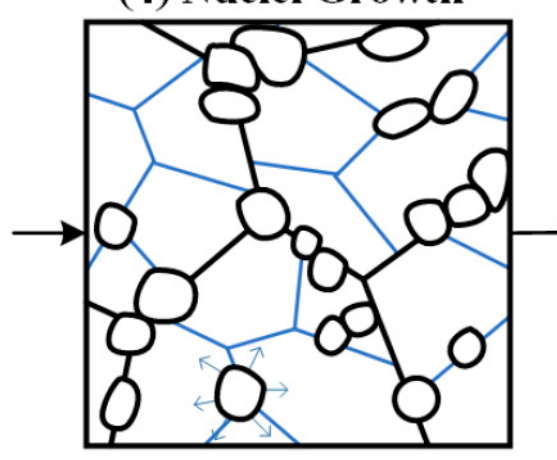

Growth into matrix
(2) Cell Structure

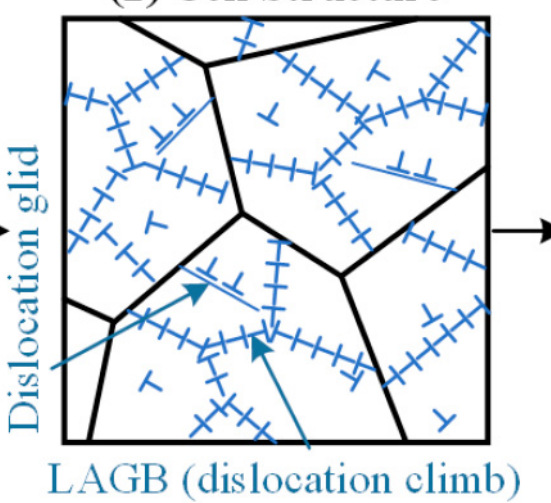

(5) Recrystallised Grain

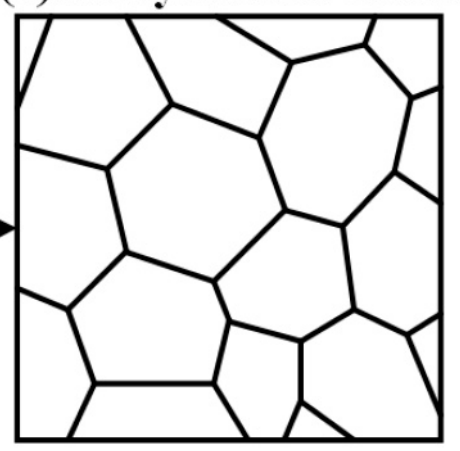

(3) Nucleation

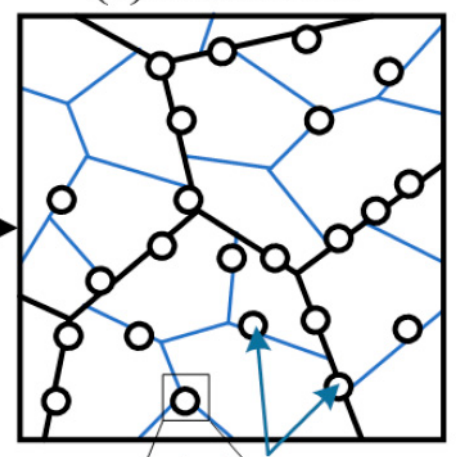

Nuqlei along GBs

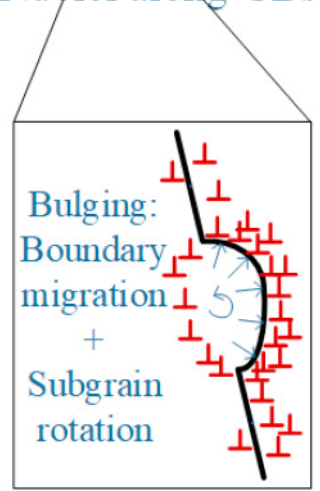

Figure 4. Schematic illustration from the development of new grains during dDRX [86].

The cDRX directly changes the orientation of sub-grains and forms new grains $[87,88]$. The cDRX steps consist of cell structure formation, sub-grain rotation and increasing of the misorientation, and conversion of grains from LAGB to HAGB [89]. During CDRX, dislocations are generated and rearranged to form LAGB sub-grains boundaries and newborn grains surrounded by HAGB. The cDRX is very common in high stacking-fault energy (SFE) materials like MSS.

In $\mathrm{gDRX}$, during hot deformation with large deformation, substantial grain refinement occurs via grain elongation and thinning. Grain elongation and thinning increase the grain boundary area dramatically [90-93]. The grain boundaries become serrated as a result of LAGB (sub-grain) formation [94]. This behavior compresses grains serrations on opposite sides that lead the grains to collapse each other, causing grain fragmentation [95]. Both gDRX and the cDRX have the same features, which are continuous growth of HAGB area and absence of nuclei [96]. At the same time, gDRX usually occurs due to large deformations when the grains are extremely elongated and thinned by grain migration $[97,98]$. The schematic view of cDRX and gDRX is shown in Figure 5a,b, respectively. 
(1) Original Coarse Grain

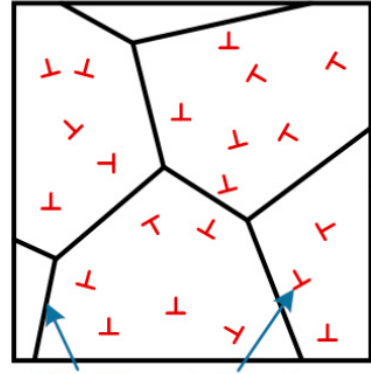

HAGB Dislocation

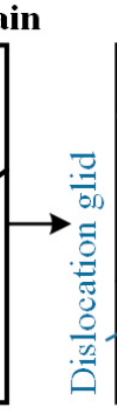

$$
\text { L }
$$

(2) Cell Structure

(3) Subgrain Rotation

(4) LAGB $\rightarrow$ HAGB

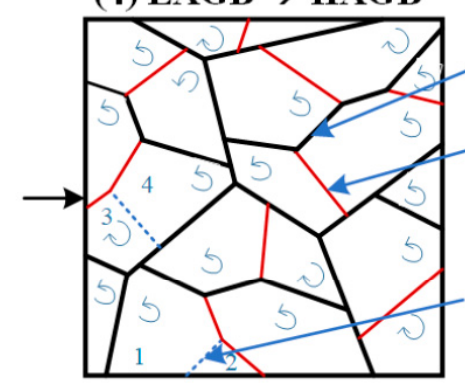

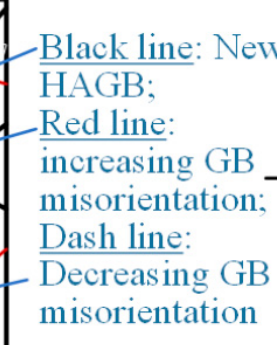

(a)

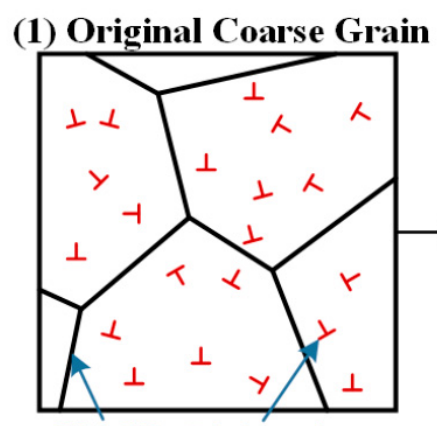

HAGB Dislocation
(2) Grain Elongation

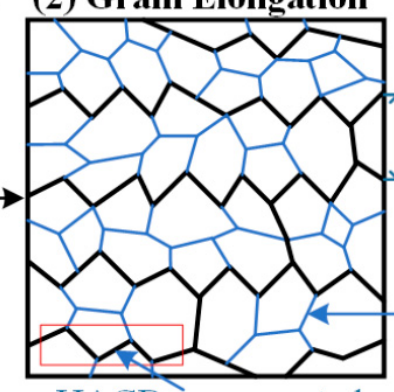

HAGBs are serrated

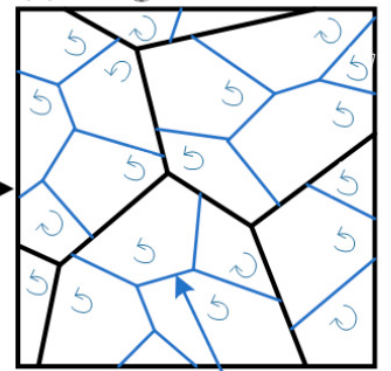

LAGB

(5) Recrystallised Grain

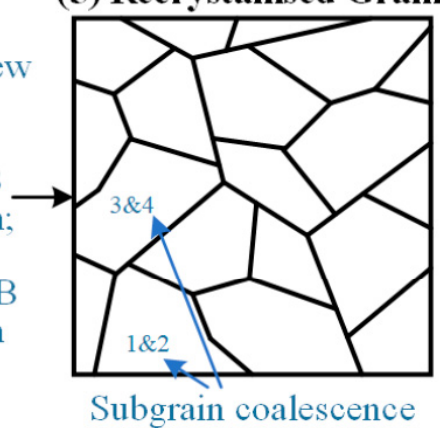

Subgrain coalescence

(3) Recrystallised Grain

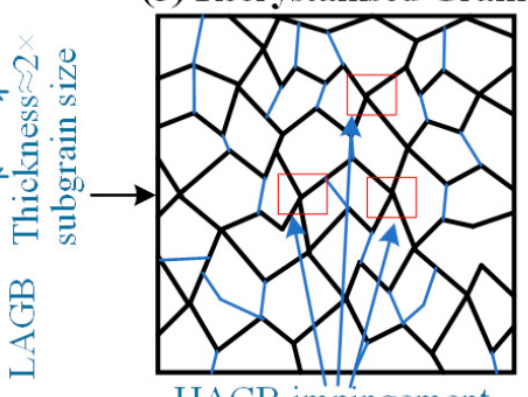

HAGB impingement

(b)

Figure 5. Schematic illustration from the development of new grains during (a) cDRX and (b) geometric dynamic recrystallization (gDRX) [86].

From a metallurgical aspect, the hot formability of an MSS is generally limited by the generation of various deformation defects [99]. At the same time, Dynamic recovery (DRV) and dynamic recrystallization (DRX) impede the accumulation of defects. Thus, the DRX and DRV are the softening mechanisms during hot forming that allow the formability of MSS and prevent defect formation [4,67]. Only a few small dynamic recrystallization grains are distributed along the grain boundary, whereas most deformed microstructures usually are composed of dynamically recovered grains. DRV is a unique flow softening mechanism that plays a softening role in counter-balance of the work hardening. As mentioned, the microstructure behavior is related to the temperature and strain rate. At high-temperature deformation of MSS, the necklace structure is formed by fine grains originated in the recrystallization at the elongated grain boundaries. It is reported that, at low-temperature and high-strain rate (in adiabatic deformation situation of MSS), different shear forces are created in diverse parts of the sample [100]. In such case, the dislocations are stuck on the interface of grain boundaries, and inhomogeneous grain distributions are 
developed [101]. Inhomogeneous grain distributions lead to internal shear force, which causes a flow localization band during hot deformation. The flow localization is an induced instability, which is undesirable for mechanical properties [102-104]. Figure 6 shows the different microstructure of $14 \% \mathrm{Cr}$ at various temperatures and strain rates in adiabatic hot deformation situations. The microstructure evolution mechanism of $14 \% \mathrm{Cr}$ MSS at different strain rates and temperatures during hot compression deformation can be divided into six regions. Partial DRX represents the region in which the DRX occurs partially, and full DRX represents the region in which the DRX occurs entirely. Flow localization occurs in the unstable region, and the grains are elongated in the DRV region [105]. During the hot compression test, when the strain rate decreases and the temperature increases, the MSS is placed in an unstable region. From a formability point of view, the undesirable microstructure forms at unstable regions due to the plastic flow localization. The plastic flow localization occurs when during hot compression of MSS, the adiabatic temperature rises at low-temperature and strain rate increases. This type of temperature strain rising in the unstable area causes different shear forces in diverse parts of the specimen. In this case, When the deformation temperature rises, the average grains become coarse after hot compression. It indicates that the power dissipation of microstructure evolution is dominated by recrystallization grains during hot deformation.

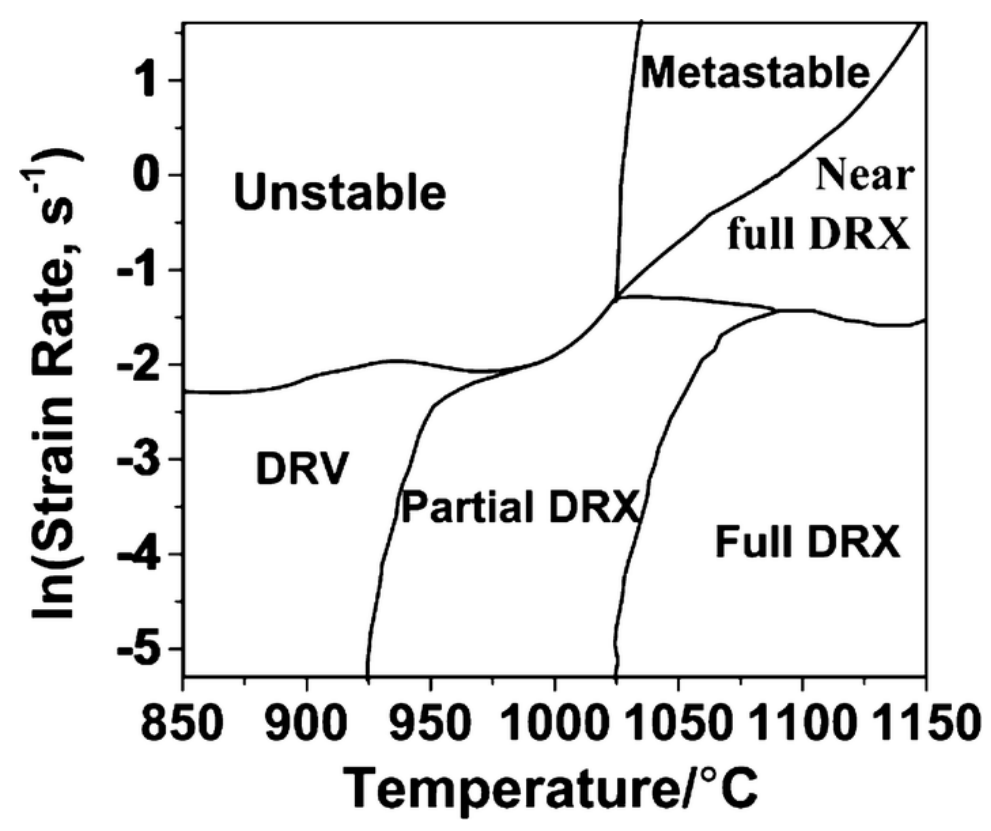

Figure 6. The microstructure evolution mechanism of $14 \%$ Cr MSS during deformation conditions [105].

Some research has been done to monitor $\mathrm{CDRX}$ with imaging of microstructure at various strains [32]. It is shown that the original microstructure of the 17-7PH MSS is austenite matrix $(\gamma)$ with the coaxial ferrite phase and $\delta$ ferrite. Figure 7 shows the microstructure of deformed 17-7PH MSS samples at $950{ }^{\circ} \mathrm{C}$ and strain rate of $0.01 \mathrm{~s}^{-1}$ at strains of $0.15,0.3$, 0.45 , and 0.6. It is shown that the $\gamma$ grains and $\delta$ islands have almost remained equiaxed at low strains (0.15). In the middle of this sample, work hardening region as the serrated grain boundaries detected that indicate the progress of DRV in the substructure. The appearance of serrated grain boundaries at low strains is a sign of fast DRV in the 17-7PH MSS. Some small grains, presumably due to DRX, are appeared around the original grain boundaries and the necklace structure in the early stages of recrystallization not observed. 

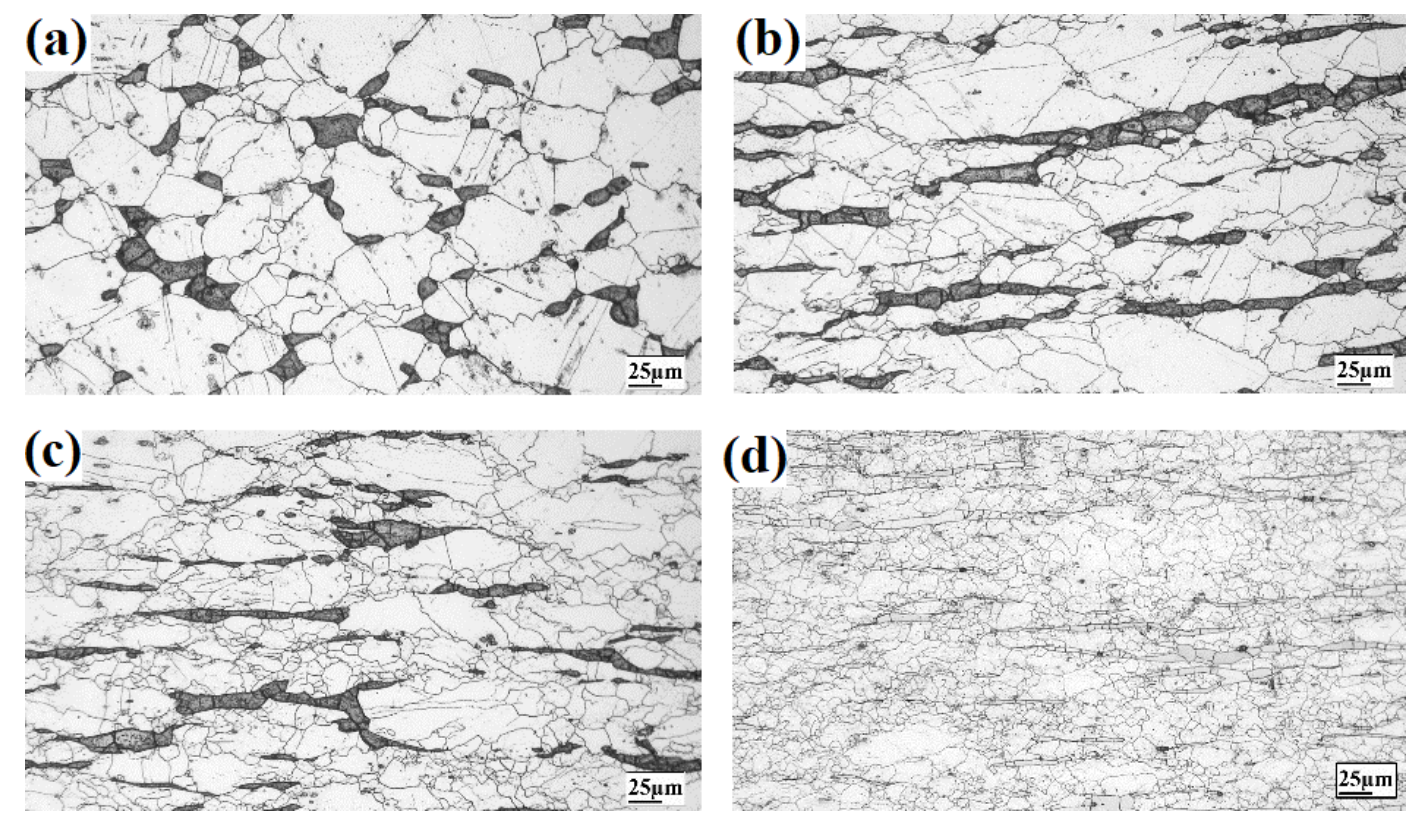

Figure 7. Microstructure of deformed samples at $950{ }^{\circ} \mathrm{C}$ and strain rate of $0.01 \mathrm{~s}^{-1}$ to strain of (a) 0.15 , (b) 0.3 , (c) 0.45 and (d) 0.6 [106].

The absence of necklace structure indicates that the probability of dDRX, which occurs through the nucleation and growth of new grains almost at prior grain boundaries, is very weak in this steel [106]. The number of new cDRX grain has increased as deformation continues, and the matric and $\delta$ islands are elongated perpendicular to the compression direction. The new grains are observed inside the elongated original grains and along the grain boundaries. With increasing strain, decomposition and combination of the subgrain boundaries could lead to the formation of HABs, which are the result of the rapid growth of the sub-grains during hot plastic deformation $[107,108]$. As the deformation continues and the strain increases to the number of recrystallized grains increases again. At high strain, the dissociation of original grains by the cDRX grains has progressed, and the fraction recrystallization increased. In this alloy, some islands of original deformed grains were detected that revealed that the microstructure of a PH7-17 has not been fully recrystallized even at high strain during the hot compression test. In the same case, if the strain rate increased, the progress of DRV decreased at low strain, which is responsible for the formation of serrations on the grain boundaries. The reduction of deformation time due to the increase in the strain rate has probably led to a limitation of diffusion and the difficulty of dislocation's motion. The weakness of DRV at a higher strain rate possibly retards the evolution of sub-grains and, therefore, postpones cDRX [106].

Figure 8 shows the microstructure of $12 \%$ Cr MSS after $0 \%, 25 \%$ and $50 \%$ hot compression [57]. The original austenite in base metal has disappeared, while there is a high number of small sub-grains formed with an increase of deformation. The gDRX has been observed at elevated temperatures where sub-grain boundary formation has been observed. The $\mathrm{gDRX}$ is detected during hot deformation at a very high strain $[81,95,109]$. After gDRX, the initial grains of the sample are fragmented into the new smaller grains with HABs. With gDRX, the HAB area can dramatically increase at high stacking fault energy (SFE) metals, but not in the same way as cDRX [110]. The cDRX includes the sub-grains boundaries' misorientation. The misorientation of sub-grains by cDRX is just a few degrees and much lower than HABs. The sub-grain boundaries are mobile and annihilate with other boundaries decreasing the sub-grain size throughout large strain hot deformation [111-113]. In cDRX, sub-grains transform into new grains within the deformed original grains. When the dislocations accumulate progressively in LAGBs, the formation of HAGBs proliferates, leading, consequently, to an increase of misorientation [112]. Deformation conditions like 
temperature and strain rate determine the number of sub-grains and stored energy after hot forming.
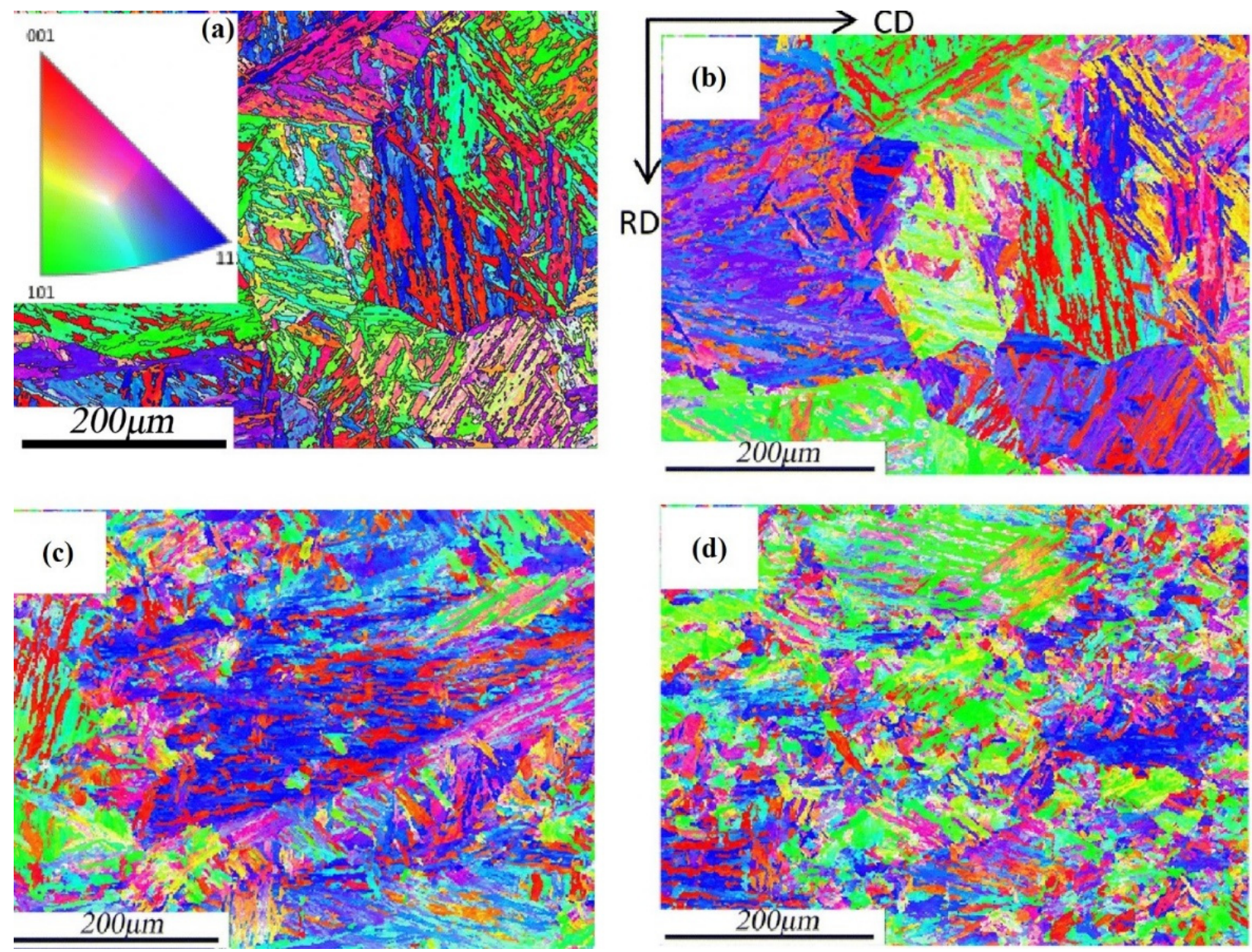

Figure 8. (a) Initial microstructure of $12 \mathrm{Cr}$ USC rotor steel, microstructure of rotor steel at $1050{ }^{\circ} \mathrm{C} / 0.01 \mathrm{~s}^{-1}$ with different deformations (b) $0 \%$, (c) $26 \%$, (d) $50 \%$ [57].

In the hot forming of MSS at a low strain rate, DRV is the main softening phenomenon because there is enough time for dislocation to climb and cross-slip [114]. Low-angle grain boundaries are formed by the migration of dislocations and have a lower energy state [115]. Generally, during hot deformation of MSS at low-temperature and high strain rate, only a few DRX grains form along the boundaries, whereas most deformed microstructures are DRV grains. The local bulging of grain boundaries is frequently observed as the initial step to the nucleation of DRX, which is often termed as strain-induced grain boundary migration (SIBM) [116]. From an industrial point of view, DRX is very important since it is a common microstructural phenomenon during the hot forming processes of MSS [117]. For the industrial hot forming process, determining the required strains for the initiation and completion of DRX is necessary. It is almost proved that during hot forming, the build-up of dislocation density reaches a critical value from which grain boundaries start to bulge through SIBM [117]. Quite close to the peak strain (critical strain) of the DRX flow curve, SIBM happens [118]. Locally bulged boundaries sweep away dislocations and cause a drop in the work hardening rate under the control of dynamic recovery [119]. After the critical point, the local bulges in boundaries grow to occupy the prior boundaries and form the necklace structure at the peak [120]. The kinetics of DRX beyond the peak determines the strain required to reach the steady-state flow. It is, therefore, evident that 
the critical peak and steady-state strains are essential in characterizing the DRX behavior of a particular alloy.

In most MSS, hot deformation is performed in the stable region of the austenite phase, where DRX is the dominant microstructural modifying mechanism [120]. Therefore, it can be a desirable process to take advantage of DRX to refine the microstructure of austenite and to prevent deformation defects prior to the transformation into martensite [121]. The softening due to DRX results in a flow stress decrement after work hardening, leading to a steady-state regime associated with the dynamic balance between work hardening and flow softening [122]. The steady-state flow dominated by the occurrence of DRX prevents the formation of plastic instabilities and results in microstructural modification [106,123,124]. In MSS, the distance between the partial dislocations is short, and for this reason, during hot forming, the cross-slipping of dislocations happens easily. The dislocation migration prompts the annihilation and rearrangement of dislocations, which can decrease the dislocation density, lower the amount of stored energy and eventually retard DRX [115]. This leads to DRV forms during hot forming. Also, at different strains, elongated and recovered grains can be seen in MSS microstructures. Increasing the strain during hot forming is advantageous to drop the size of the average substructure and refine the MSS microstructure. This emanation results in an increase in dislocation density and in the number of LAGBs, which is beneficial to reduce the average substructure size and to refine the microstructure. On the other hand, the dislocation migration can be promoted by increasing the temperature during the deformation process [125]. The microstructure changes during the hot compression test of AISI 420 steel is depicted in Figure 9 .

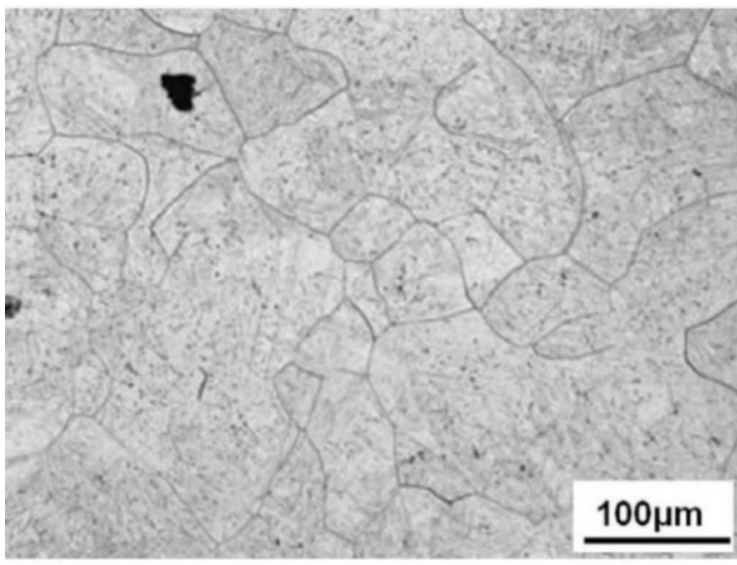

(a)

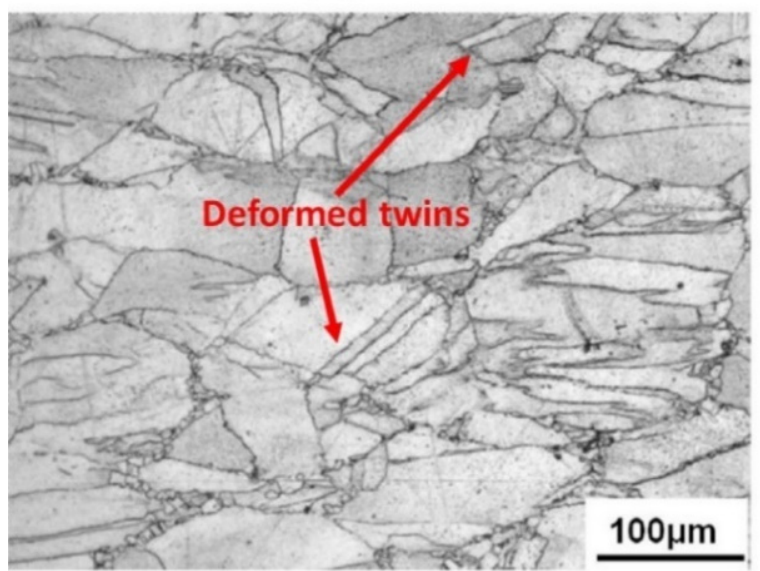

(c)

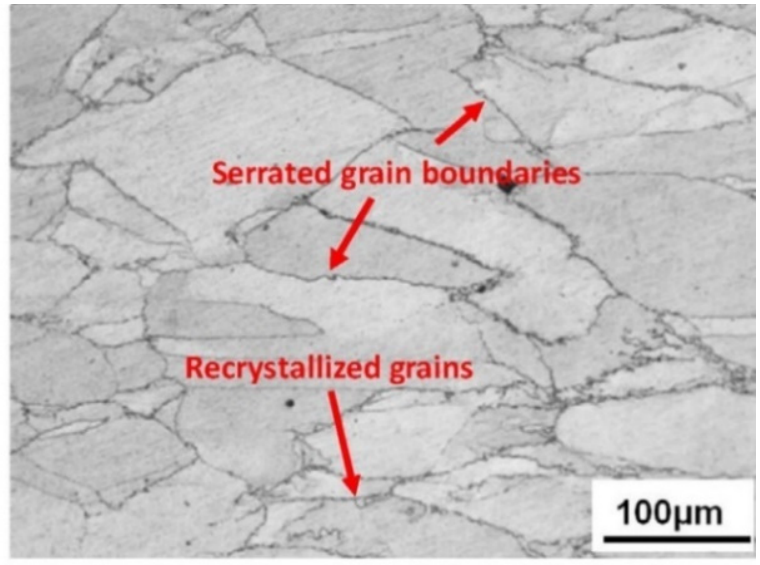

(b)

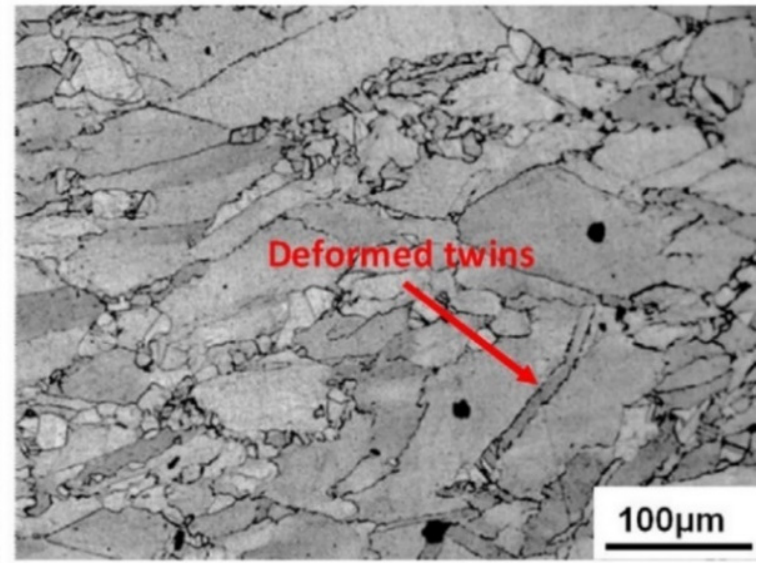

(d)

Figure 9. (a) Initial microstructure and typical microstructures of AISI 420 martensitic stainless steel deformed at a true strain of 0.7 under different conditions: (b) $1223 \mathrm{~K}, 0.1 \mathrm{~s}^{-1}$, (c) $1273 \mathrm{~K}, 10 \mathrm{~s}^{-1}$ and (d) $1373 \mathrm{~K}, 10 \mathrm{~s}^{-1}$ [61]. 
The micrograph of base metal revealed coarse austenite grains with $158 \mu \mathrm{m}$ size. At the deformation temperature of $1223 \mathrm{~K}$ and strain rate of $0.1 \mathrm{~s}^{-1}$, the original coarse austenite grains are elongated, and some sub-grains are formed along boundaries (Figure 9b). Microstructure investigation revealed that the DRX is insufficient and incomplete in high strain rate $\left(10^{-1}\right)$, and partial DRX or DRV was detected as the primary deformation mechanism. Some serrated grain boundaries, together with local bulges, were observed on the newly formed boundaries. The reason may be that the grain boundary (or deformation band) has a larger driving force and more nucleation sites for DRX. It seems that the larger density of dislocation in the corresponding regions is the root of this phenomenon. Figures $8 \mathrm{~d}$ and $9 \mathrm{c}$ show the typical microstructures of the deformation twin phenomenon, deformed at the strain rate of $10 \mathrm{~s}^{-1}$ and the deformation temperature $1273 \mathrm{~K}, 1373 \mathrm{~K}$, respectively. The deformation twin phenomenon may be that the grain deformation and grain boundary sliding are inhibited by the low-level dynamic recovery [61].

The obtained microstructure at different thermo-mechanical regimes of stable deformation during hot forming of 410 MSS shows an equiaxed appearance of original austenite grains extracted from the final martensitic structure, which implies the occurrence of DRX. It is very well documented that grain size remains almost unchanged at strains over the onset of steady-state flow. The steady-state grain size, also known as DRX grain size, increases with temperature, decreasing with strain rate. This demonstrates that DRX grain size is almost independent of the initial grain size. Therefore, different models are recommended to express the dependence of DRX grain size to processing parameters incorporated in the Zener-Hollomon parameter (Z). Thus, concluded that DRX grain size depends on the $Z$ parameter and is almost independent of the initial grain size so that the DRX grain size decreases with an increase in the Z [126].

Kishor et al. studied the characteristics of $13 \mathrm{Cr}-4 \mathrm{Ni}$ microstructure during hot deformation [62]. The optical microstructure of ASR 13Cr-4Ni martensitic stainless steels before the deformation is shown in Figure 10a, consisting of a full-lath martensite structure. According to the achieved results, after the hot deformation, all the microstructures predominantly exhibited a martensitic structure for all the deformation conditions. Microstructural evolution after hot deformation was characterized to validate the occurrence of DRX and to confirm the stable and unstable regions. Uniform grain growth and small equiaxed grains along the grain boundaries were observed at the deformation conditions of $1000{ }^{\circ} \mathrm{C}, 0.001 \mathrm{~s}^{-1}$ and $1050{ }^{\circ} \mathrm{C}, 0.1 \mathrm{~s}^{-1}$, as can be seen in Figures $9 \mathrm{c}$ and $10 \mathrm{~b}$, respectively. These features demonstrate the occurrence of DRX that was achieved by optimum hot working domains. For $950^{\circ} \mathrm{C}, 0.1 \mathrm{~s}^{-1}$ deformation condition (Figure 10d), the microstructure revealed partially recrystallized features (seen as equiaxed grains) and remaining recovered structure (seen as inhomogeneous distribution of grains). This is representative of the incomplete softening mechanism during $950{ }^{\circ} \mathrm{C}, 0.1 \mathrm{~s}^{-1}$ deformation condition. Microstructure in Figure 10e corresponding to the instability region $900{ }^{\circ} \mathrm{C}, 10 \mathrm{~s}^{-1}$ revealed localized flow structure and shear bands (marked by arrow) due to the absence of steadystate behavior. It also shows refined grains formed due to recrystallization within the bands. According to the processing map, this condition is located in the instability region.

Microalloying of MSS can change the DRX during hot deformation. The standard and well-known element in MSS is niobium $(\mathrm{Nb})$ that has an intense effect on DRX. The microstructure changes of MSS micro-alloy during the hot compression test are shown in Figure 11. The initial microstructure was a completely coarse equiaxed austenitic grain structure. At a low strain rate, the austenite grains were elongated, and DRX was not detected. Many $\mathrm{Nb}$ precipitates with lamellar shape appeared alongside the austenite grain boundaries. With increasing temperature, the precipitates along grain boundaries decreased, and a small amount of DRX with fine grains formed in hot deformed areas. It is proved that a high density of dislocations could be produced during the martensitic transformation and distribution of a large number of nanosized precipitates [127]. 

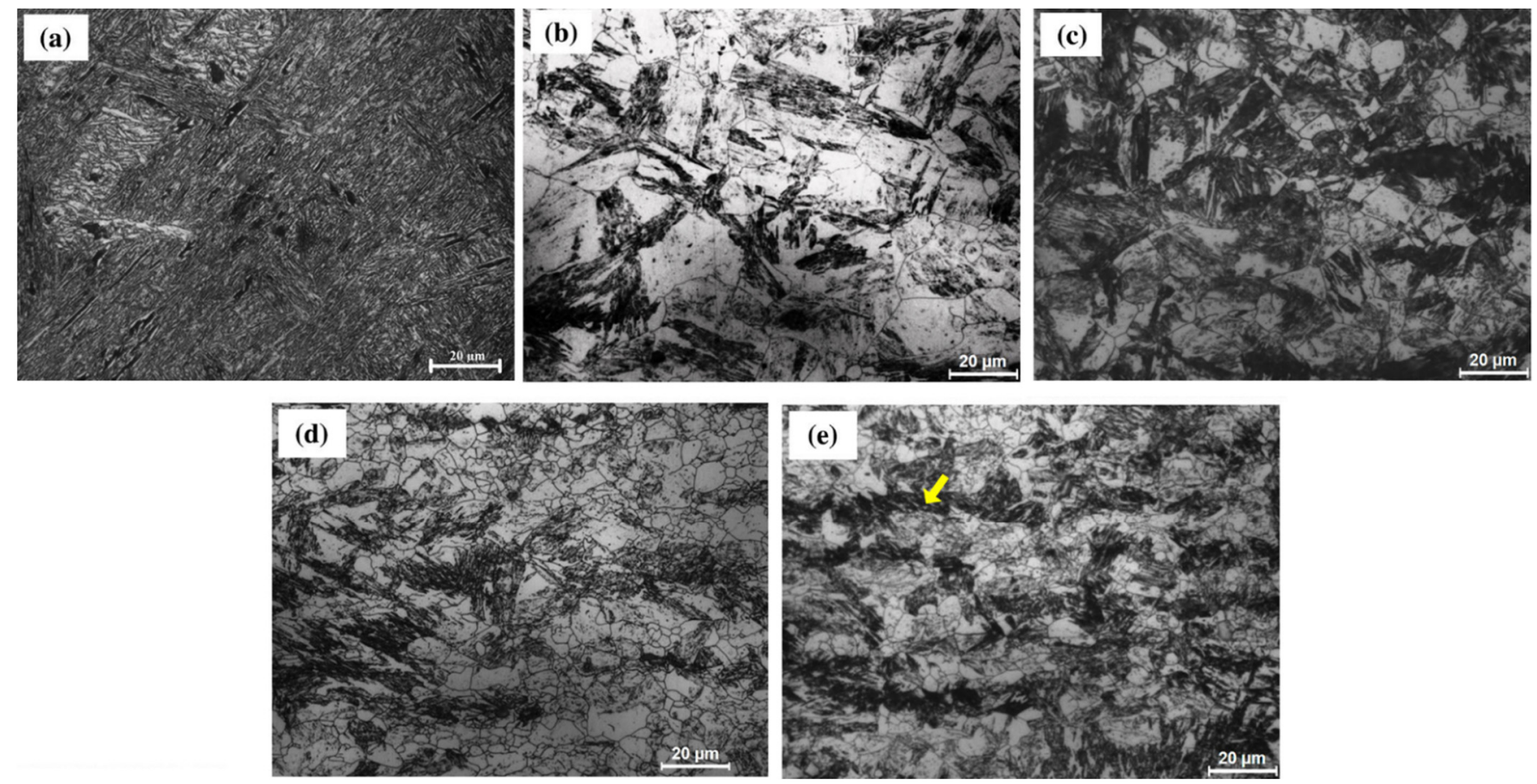

Figure 10. Optical micrographs of (a) as-received MSS, and hot deformed specimens exhibiting dynamic recrystallization $(\mathrm{DRX})$ at the deformation conditions of $(\mathbf{b}) 1000{ }^{\circ} \mathrm{C}, 0.001 \mathrm{~s}^{-1}$, (c) $1050{ }^{\circ} \mathrm{C}, 0.1 \mathrm{~s}^{-1}$. Incomplete restoration characteristics are observed for deformation condition of $(\mathbf{d}) 950^{\circ} \mathrm{C}, 0.1 \mathrm{~s}^{-1}$. Instability features are observed in (e) $900{ }^{\circ} \mathrm{C}, 10 \mathrm{~s}^{-1}$ specimen [62].
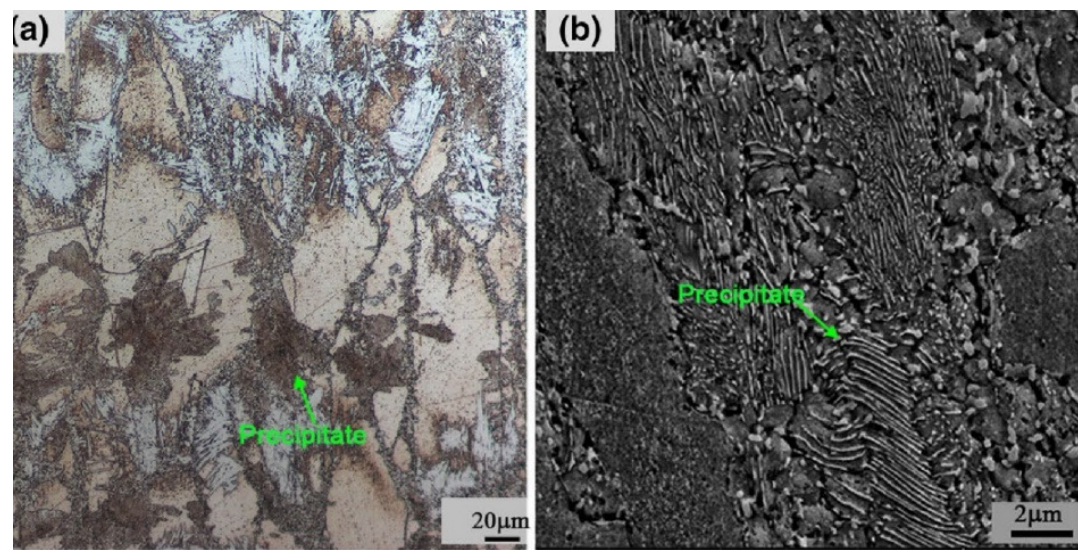

(c)
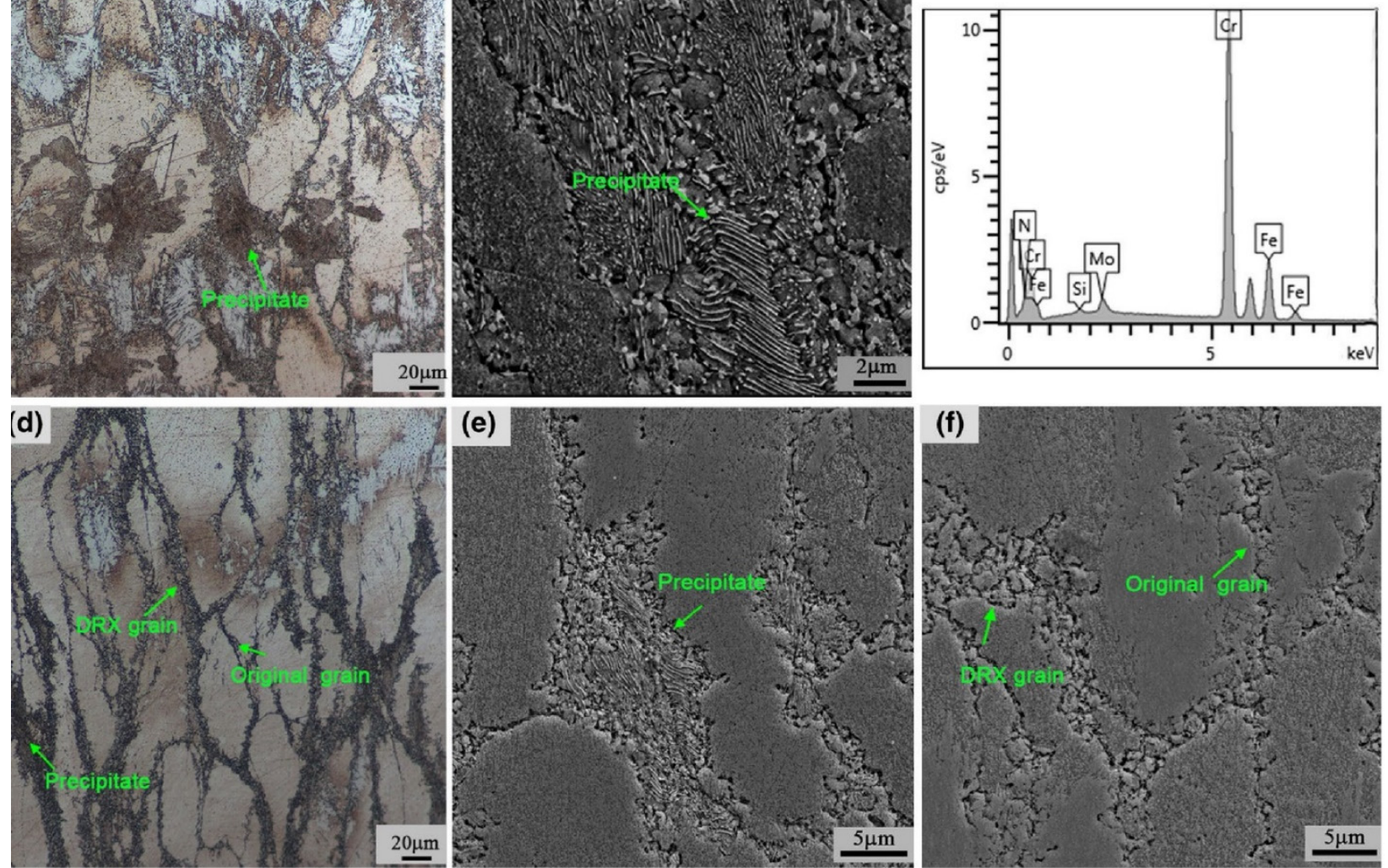

Figure 11. Microstructures of $15 \%$ Cr MSS deformed with a strain rate of $0.005 \mathrm{~s}^{-1}$ at temperatures of $(\mathbf{a}-\mathbf{c}) 1223 \mathrm{~K},(\mathbf{d}-\mathbf{f})$ $1273 \mathrm{~K}$ [127]. 
Restoration mechanisms in metals during hot work have been one of the main issues in recent decades. In most cases, DRV has been reported as the only restoration mechanism for alloys with high stacking fault energy [128,129]. Besides, in metals and alloys with high SFE, cDRX occurs instead of dDRX. cDRX plays a prominent role in producing finer grains through hot deformation [3-5]. This mechanism mostly occurs in low carbon ferritic steels and even to some extent in austenitic stainless steels as well as MSS [130]. Generally, ferritic microstructures prefer the work softening by an extended DRV, resulting in cDRX at higher applied strains $[88,131]$. Dynamic restoration leads to an increase in the density of dislocations at LAGBs, thereby transforming them into HAGBs [132]. It accepted that sub-grains might rotate to the point that the adjacent sub-grains reach a similar orientation due to boundary diffusion processes [133]. In this case, already existing LAGBs will be deleted [11]. These sub-grains will combine and convert to larger subgrains. The driving force necessary for this process will be obtained by decreasing the surface area of LAGBs in unit volume [134].

\section{Analysis of MSS Flow Stress under Hot Deformation}

Metals flow stress graph relates strain, strain rate and temperature. Many mechanical or metallurgical parameters could change the results of flow stress. The addition of alloying elements in MSS could increase the flow stress value and reduce the hot workability. The properties of stress-strain graph are determined by the deformation temperature, strain rate, microstructural, and the final crystallized grain size. Generally, the flow stress decreases with increasing temperature and increases with increasing strain rate at a constant parameter during compression test [77].

During hot deformation of MSS, three types of flow stress graphs have been reported that indicate that there are cDRX and DRV [135]. In the first case, during high-temperature plastic forming, the flow stress graph shows a continuous increase until reaching saturation stress. This behavior, depicted in Figure 11a, indicates a steady state of flow, which is the result of strain hardening decrease during deformation. In these cases, DRV is the main restoration process during hot deformation [136]. This type of graph is usually seen during hot deformation of MSS with low strain rates $(\varepsilon<1)$, and it is justified by the fact that the softening produced by DRV is able to balance the strain hardening rate. In the second case, which is referred to as the dDRX phenomenon, the flow stress graph in high-temperature compression shows a gradual increase until it reaches a stress peak (Figure 12). Then with increasing strain, the flow stress decreases until a steady-state trend. In exceptional cases, some decreasing peaks of heights form before the steady-state behavior. During straining (from starting point and before reaching peak stress), the graph's increase is the result of new grains appearance, which leads to softening due to decreasing the rate of work hardening. After the peak stress, the steady flow stress is the result of the dynamic equilibrium existing between strain softening and strain to harden. This dynamic equilibrium is the result of new grains formation with grain boundary migration. The third type of graph is obtained at high strain rate $\left(5^{-1}\right)$ experiments. In these cases, DRV occurs in the substructures at the early stage of straining and sub-grains misorientations till they attain $\mathrm{HAB}$ values $[84,87,112,135]$. During the hot forming of MSS, the relation between the $\mathrm{DRV}$ rate and the grain boundaries migration velocity determines the formation of $\mathrm{dDRX}$ and cDRX. With increasing temperature, the critical strain for the dDRX decreases, which leads to a reduction in metal grain size [135,137]. The addition of elements in MSS during production can affect the flow stress during hot deformation. For example, Niobium $(\mathrm{Nb})$ precipitates effectively postpone or inhibit DRX in MSS. During hot deformation, $\mathrm{Nb}$ atoms impose solute dragging force on the moving dislocations and grain boundaries. 


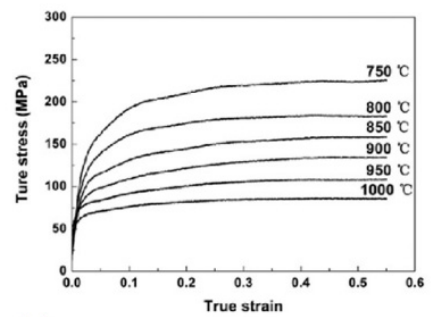

(a)

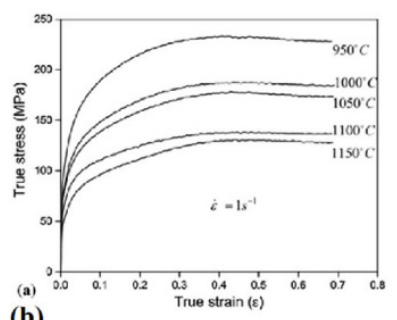

(b)

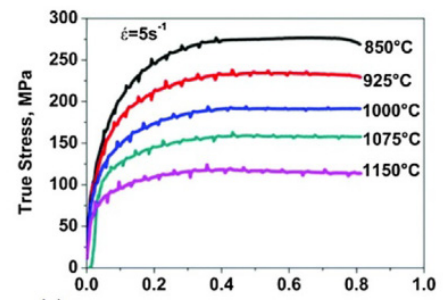

(c)

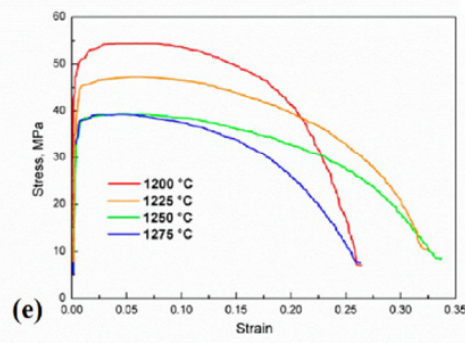

(d)

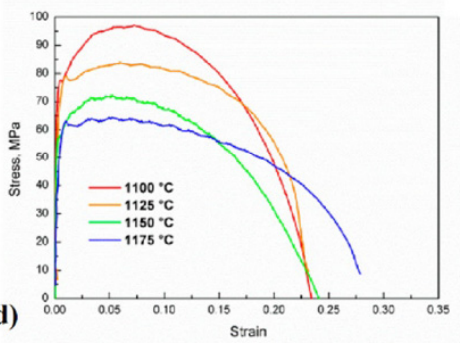

(e)

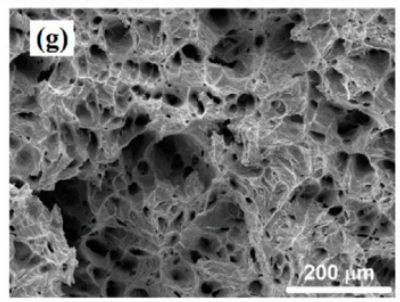

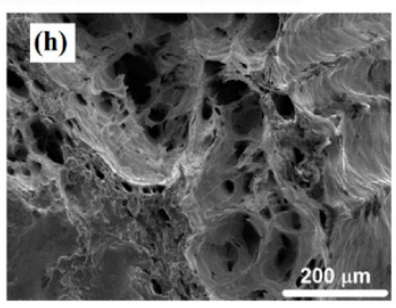

Figure 12. Obtained stress-strain curves after the hot compression test of MSS that shows (a) DRV in 17\% Cr MSS, (b) dDRX in $12 \%$ Cr MSS and (c) cDRX in 14\% Cr MSS [105]. (d,e) hot tension curves of 13CrMoNbV steel at temperatures in the range of $1100^{\circ} \mathrm{C}-1275^{\circ} \mathrm{C}(\mathrm{dr} 1)$. Microstructure of the tensile samples' fractured surface after deformation at (f) $1100{ }^{\circ} \mathrm{C},(\mathrm{g})$ $1150{ }^{\circ} \mathrm{C}$ and (h) $1200{ }^{\circ} \mathrm{C}[138]$.

In another type of hot testing, a hot tensile test has been done on $13 \mathrm{CrMoNbV}$ steel. The engineering stress-strain curves of the steel at various temperatures are depicted in Figure 12d,f [138]. The increasing temperature decreased the engineering stress during the tensile test, similar to the hot compression behavior. On the other hand, the ultimate tensile strength values increase with decreasing temperature. The $13 \mathrm{CrMoNbV}$ steel shows high values of plasticity in the range of $1100{ }^{\circ} \mathrm{C}-1275^{\circ} \mathrm{C}$ [138]. The fracture surface of tensile samples consists of traces of intensive deformation before failures, such as microvoids, dimples, and sharp crests. The fracture surface becomes more heterogeneous with a temperature increase from $1100{ }^{\circ} \mathrm{C}$ to $1200^{\circ} \mathrm{C}$. The dimples' size increases with increasing deformation temperature due to a more intensive plastic deformation and the coalescence of micro-voids during a longer deformation process at high deformation temperatures [139].

\section{Precipitates and Dislocations}

Generally, the martensitic matrix of MSS contains precipitates after thermo-mechanical processing. Depending on the strain rate and temperature, the size of precipitates and also morphologies of obtained martensite after transformation could be different [140]. During thermo-mechanical processing of MSS, the probability of nanosized precipitates formation and density of dislocations increase. During the hot working, the martensitic matrix changes to martensitic blocks, and the blocks are further divided into several parallel laths [141-145]. TEM images of martensitic lath and precipitates in $403 \mathrm{Nb}$ steel after hot working are shown in Figure 13. The small-block and martensitic lath are detectable in the TEM images. The large carbides (thick black arrows), nanosized MX carbides (thin black arrows), and undissolved precipitates (white arrows) arisen during solid solution treatment are detected [146]. The big carbides that mostly had $\mathrm{M}_{23} \mathrm{C}_{6}$ chemical composition 
precipitated along with the martensite lath and blocks. This carbide type is regularly detected in conventional 9-12\% Cr steel [147-149].
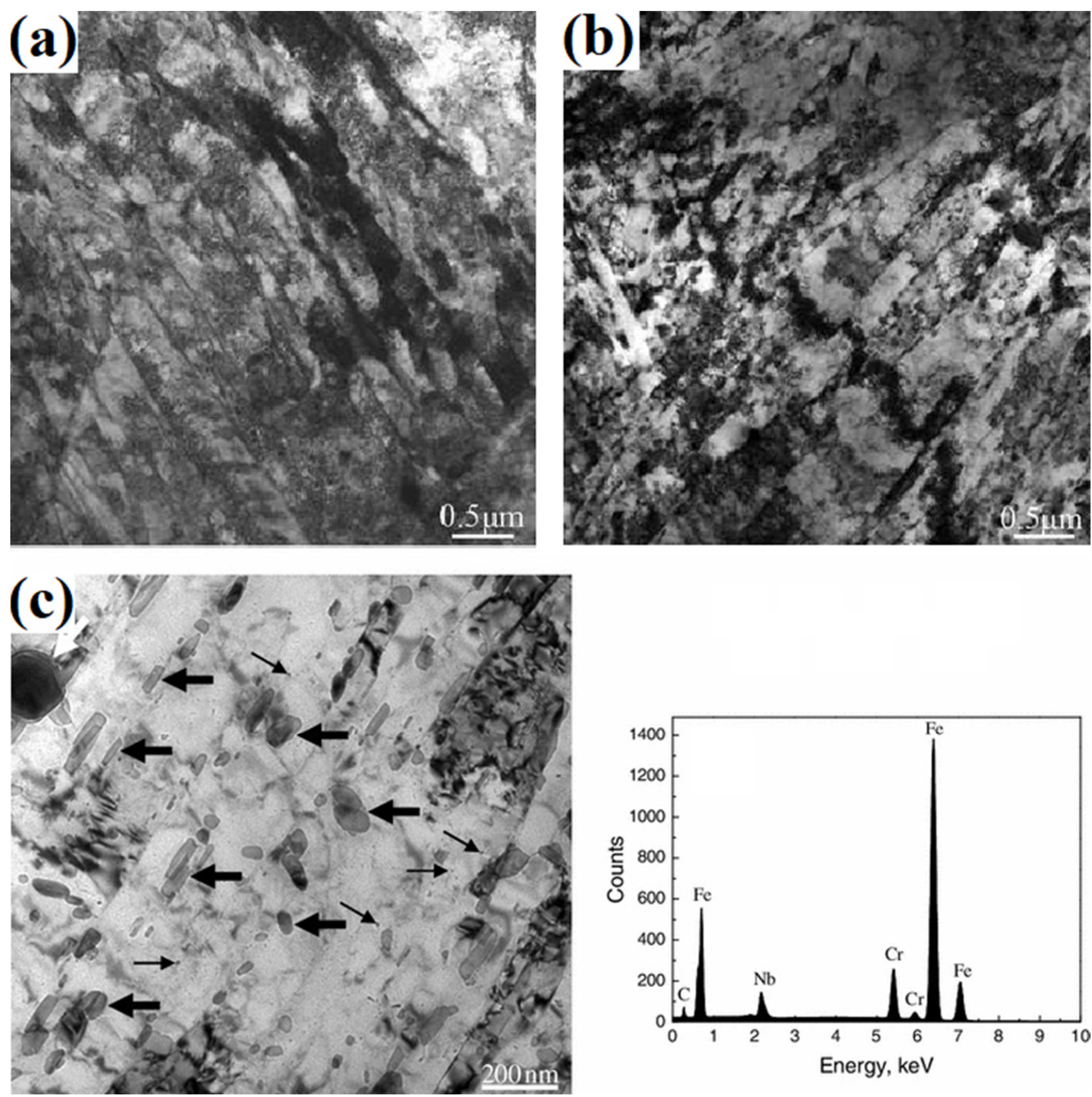

Figure 13. (a,b) TEM images showing the martensitic lath of $403 \mathrm{Nb}$ steel after thermomechanical treatment, (c) TEM images showing the MX carbides precipitate of $403 \mathrm{Nb}$ steel [141].

$\mathrm{NbC}, \mathrm{Cr} 2 \mathrm{~N}, \mathrm{M} 23 \mathrm{C} 6$ carbides are detected in precipitation MSS grades [45]. In this type of MSS, the increase in strain rate rapidly increases the deformation energy in unit time, which leads to quick dislocation movement, accumulation, entanglement, and plugging, which makes the kinetic recovery and recrystallization incomplete [150]. Because of the solid solution in steel, nitrogen retards the growth of the detrimental intermetallic phase, and the precipitation of nitride and M23C 6 causes hardening of the grain boundary [151]. With increasing hot compression test temperature, the atomic kinetic energy increases, and the thermal deformation is more easily activated. Simultaneously, dynamic recrystallization nucleation becomes easier, and the high-temperature dynamic recrystallization process 
is accelerated. These two factors greatly accelerate the softening process and reduce flow stress. In Cu-bearing MSS, the degree of dynamic recrystallization is tremendous, and for starting DRX lower strain rate is needed. In this type of MSS, the $\mathrm{CrN}$ and $\mathrm{Cr} 23 \mathrm{C} 6$ phases were detected during hot compression, strengthening the grain boundary and significantly affecting the strain limit of the material [152].

The fine MX carbides are distributed mainly within that lath and along boundaries. In some cases, deformation-induced phase transformation caused an increase of dislocation density in the martensite and induced a concentration of dislocations at the boundaries [153]. During the hot forming, the piling up of dislocations on the boundaries creates internal stress concentration [154]. Furthermore, the number of dislocations in martensite lath boundaries increased. Therefore, the density of dislocations near the transformed lath is much higher than in the initial martensite matrix $[155,156]$.

During the hot compression test of MSS, the metal atoms can diffuse sufficiently at a low strain rate, which is advantageous for the occurrence of dynamic recrystallization [157]. At low strain rates, the longer DRX times make it easier for recrystallized grains to grow [158]. Further, a lower strain rate results in less coarse energy obtained by metal deformation. Consequently, the recrystallization driving force decreases accordingly, and the area where recrystallization can occur also decreases simultaneously [159]. In precipitation MSS grades, carbides at grain boundaries have hindered the movement of dislocations, grain boundary slip, and metal recrystallization growth. During hot compression test, at low-temperature and low strain rate, these carbide remains in the microstructure of MSS, but at a higher temperature and high strain rate, the carbides at grain boundaries gradually dissolved into the matrix [160]. On the other hand, at the high-temperature compression test, it is shown that during the high strain rate hot compression test of MSS, the number of carbides at grain boundaries was reduced [161]. This phenomenon indicated that strain is greater than the time effect on dissolving of carbides. This issue can be used in the processing efficiency of MSS [162]. The carbide precipitates dissolved at the grain boundaries, thereby weakening the pinning effect on grain boundaries, and consequently, DRX was easier to occur in precipitation MSS grades at a higher temperature [163].

\section{Summary and Further Investigation}

The main contributions of the experimental characterization of dynamic recrystallization of martensitic stainless steels during hot deformation are analyzed in this paper, focusing on its applicability to bulk forming operations.

The experimental technique mostly used for the characterization of MSS workability in hot forming conditions is the hot compression test, as for most metals. Flow stress behavior of the material under different plastic deformation conditions are obtained, as well as relevant information of grain evolution that has been used for understanding DRX phenomena. There are three types of DRX: discontinuous, continuous and geometrical. In the dDRX, dislocation motion and accumulation favor new grain nucleation at grain boundaries leading to a new finer cell structure. It is rarely reported in high chromium MSS during hot deformation since it is related to low and medium stacking-fault energy (SFE) steels, and MSS are in the category of high SFE materials. The cDRX directly changes the orientation of sub-grains and forms new grains. During CDRX, dislocations are generated and rearranged to form LAGB sub-grains boundaries. The cDRX is very common in high stacking-fault energy (SFE) materials like MSS. Finally, gDRX is a mechanism of grain refinement by grain elongation, thinning, and fragmentation. gDRX and the cDRX have the same features, which are continuous growth of HAGB area and absence of nuclei. These types of grain refinement added to the analysis of stability have been recurrently studied in the literature reviewed for different grades of MSS.

Regarding the analysis of MSS flow stress during hot deformation (at temperatures above $0.5 \mathrm{~T}_{\mathrm{m}}$ ), it has been found that DRV and DRX phenomena counteract strain hardening and lead to strain softening at large strains. In MSS, as high SFE materials, deformation is controlled mainly by DRV, especially at low strain rates $\left(\dot{\varepsilon}<1 \mathrm{~s}^{-1}\right)$. During hot forming, 
the redisposition and annihilation of dislocations readily happen over DRV, leading to the formation of subgrains. DRV and cDRX cause strain-softening of MSS during hot deformation. In cDRX, a critical strain is needed to nucleate new grains and HABs are formed during high strain deformation conditions. These new grains contain high densities of dislocations. The grains structure after cDRX is nearly homogeneous.

In addition, the presence of precipitates, main carbides of different compositions ( $\mathrm{NbC}$, $\left.\mathrm{Cr}_{2} \mathrm{~N}, \mathrm{M}_{23} \mathrm{C}_{6}\right)$ and $\mathrm{Cr}$ compounds $\left(\mathrm{CrN}\right.$ and $\left.\mathrm{Cr}_{23} \mathrm{C}_{6}\right)$ cause hardening of the grain boundary, facilitates the activation of thermal deformation and ease the nucleation of the DRX process. As a result, an acceleration of the softening process and a reduction of flow stress are usually observed in MSS under high-temperature forming conditions due to precipitations. Despite the significant effort made in studying the microstructural structures of MSS produced by DRV and DRX reviewed here, some notable features remain to be explained. First, the application of cDRX to microstructure control in MSS grades does not consider allotropic transformations. Second, the effects of the continuous multiphase hot bulk metal forming on the DRX of MSS have not been considered. In hot bulk metal forming, the sub-DRX and microstructural changes could be interesting. Third, the deformation twinning role in producing $\mathrm{CRDX}$ grain refinement is also an interesting contribution for the future.

Author Contributions: Conceptualization, H.A.D., A.M.-M., D.M., and E.G.G.; software, H.A.D.; validation, E.G.G., A.M.-M. and D.M.; formal analysis, H.A.D., A.M.-M., D.M., and E.G.G.; investigation, H.A.D., A.M.-M., D.M., and E.G.G.; resources, H.A.D.; data curation, H.A.D., A.M.-M., D.M., and E.G.G.; writing—original draft preparation, H.A.D.; writing—review and editing, H.A.D., A.M.-M., D.M., and E.G.G.; supervision, E.G.G.; and D.M.; project administration, E.G.G.; All authors have read and agreed to the published version of the manuscript.

Funding: This project has received funding from the European Union's Horizon 2020 Research and Innovation Programme under the Marie Skłodowska-Curie grant agreement No. 847624. In addition, a number of institutions back and co-finance this project.

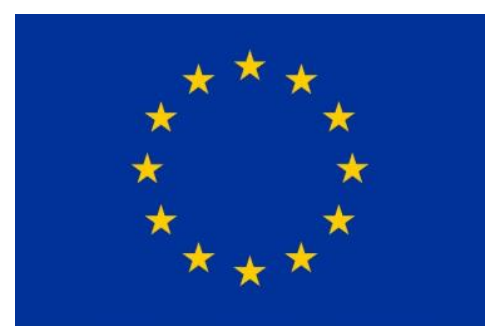

Institutional Review Board Statement: Not applicable.

Informed Consent Statement: Not applicable.

Data Availability Statement: MDPI Research Data Policies.

Conflicts of Interest: The authors declare no conflict of interest.

\section{References}

1. Stichel, W. ASM speciality handbook: Stainless steels. Hrsg. von J. R. Davis, 577 S., ASM International, Materials Park, Ohio, USA, 1994, £ 136.00 (ASM Member $£ 102.00$ ) ISBN 0-87170-503-6. In Europa zu beziehen durch: American Technical Publishers Ltd, 27-29 Knowl Pi. Mater. Corros. 1995, 46, 499. [CrossRef]

2. Hara, T.; Semba, H.; Amaya, H. Pipe and Tube Steels for Oil and Gas Industry and Thermal Power Plant; Elsevier: Amsterdam, The Netherlands, 2020; ISBN 978-0-12-803581-8.

3. Iannuzzi, M. Environmentally assisted cracking (EAC) in oil and gas production. In Woodhead Publishing Series in Metals and Surface Engineering; Raja, V.S., Shoji, T.B.T.-S.C.C., Eds.; Woodhead Publishing: Sawston, UK; Cambridge, UK, 2011 ; pp. 570-607. ISBN 978-1-84569-673-3.

4. Kim, M.-S.; Park, K.-S.; Kim, D.-I.; Suh, J.-Y.; Shim, J.-H.; Hong, K.T.; Choi, S.-H. Heterogeneities in the microstructure and mechanical properties of high-Cr martensitic stainless steel produced by repetitive hot roll bonding. Mater. Sci. Eng. A 2021, 801, 140416. [CrossRef]

5. Kassis, K.; Masmoudi, J.; Kolsi, A.W.; Dubois, B. Effect of phosphorus on the formation of titanium carbide in $17 \%$ Cr ferritic steels stabilized with titanium. Rev. Met. Paris 2004, 101, 685-693. [CrossRef]

6. Singh, R. Welding Corrosion Resistant Alloys—Stainless Steel; Singh, R.B.T.-A.W.E., Ed.; Butterworth-Heinemann: Boston, MA, USA, 2012; Chapter 6; pp. 191-214. ISBN 978-0-12-391916-8. 
7. Darvell, B.W. Steel and Cermet. In Woodhead Publishing Series in Biomaterials; Darvell, B.W.B.T.-M.S., Tenth, E., Eds.; Woodhead Publishing: Sawston, UK; Cambridge, UK, 2018; Chapter 21; pp. 540-554. ISBN 978-0-08-101035-8.

8. Dong, J.; He, Y.; Kim, M.; Shin, K. Effect of Creep Stress on the Microstructure of 9-12\% Cr Steel for Rotor Materials. Microsc. Microanal. 2013, 19, 95-98. [CrossRef] [PubMed]

9. Manilova, E. Examination of Minor Phases in Martensitic 12\% Cr-Mo-W-V Steel. Microsc. Microanal. 2006, 12, 1612-1613. [CrossRef]

10. Tanaka, T. Fatigue Strength: Improving by Surface Treatment; Buschow, K.H.J., Cahn, R.W., Flemings, M.C., Ilschner, B., Kramer, E.J., Mahajan, S., Veyssière, P.B.T.-E., Eds.; Elsevier: Oxford, UK, 2001; pp. 2990-2994. ISBN 978-0-08-043152-9.

11. Garrison, W.M. Stainless Steels: Martensitic; Buschow, K.H.J., Cahn, R.W., Flemings, M.C., Ilschner, B., Kramer, E.J., Mahajan, S., Veyssière, P.B.T.-E., Eds.; Elsevier: Oxford, UK, 2001; pp. 8804-8810. ISBN 978-0-08-043152-9.

12. Somers, M.A.J.; Christiansen, T.L. Gaseous Processes for Low Temperature Surface Hardening of Stainless Steel; Mittemeijer, E.J., Somers, M.A.J.B.T.-T.S.E., Eds.; Woodhead Publishing: Oxford, UK, 2015; pp. 581-614. ISBN 978-0-85709-592-3.

13. Webster, D. Development of a high strength stainless steel with improved toughness and ductility. Metall. Mater. Trans. B 1971, 2, 2097-2104. [CrossRef]

14. Villalobos, J.C.; Del-Pozo, A.; Campillo, B.; Mayen, J.; Serna, S. Microalloyed Steels through History until 2018: Review of Chemical Composition, Processing and Hydrogen Service. Metals 2018, 8, 351. [CrossRef]

15. Krauss, G. Physical Metallurgy of Steels: An Overview ${ }^{* *}$ Every Effort has been Made to Trace Copyright Holders and to Obtain their Permission for the Use of Copyright Material. The Publisher Apologizes for Any Errors or Omissions in the Acknowledgements; Rana, R., Singh, S.B.B.T.-A.S., Eds.; Woodhead Publishing: Sawston, UK; Cambridge, UK, 2017; pp. 95-111. ISBN 978-0-08-100638-2.

16. Yang, Q.; Zhou, Y.; Li, Z.; Mao, D. Effect of Hot Deformation Process Parameters on Microstructure and Corrosion Behavior of 35CrMoV Steel. Materials 2019, 12, 1455. [CrossRef]

17. Magnee, A.; Drapier, J.M.; Coutsouradis, D.; Habrakan, L.; Dumont, J. Cobalt-Containing High-Strength Steels; IAEA Report: Brussels, Belgium, 1974.

18. Pickering, F.B. Physical Metallurgy and the Design of Steels/F. B. Pickering; Materials Science Series; Applied Science Publishers: London, UK, 1978; ISBN 0853347522.

19. Zhang, H.; Wei, Z.; Xie, F.; Sun, B. Assessment of the Properties of AISI 410 Martensitic Stainless Steel by an Eddy Current Method. Materials 2019, 12, 1290. [CrossRef]

20. Harsha, A.-P.; Limaye, P.-K.; Tyagi, R.; Gupta, A. Effect of Temperature on Galling Behavior of SS 316,316 L and 416 Under Self-Mated Condition. J. Mater. Eng. Perform. 2016, 25, 4980-4987. [CrossRef]

21. Ben Lenda, O.; Tara, A.; Lazar, F.; Jbara, O.; Hadjadj, A.; Saad, E. Structural and Mechanical Characteristics of AISI 420 Stainless Steel After Annealing. Strength Mater. 2020, 52, 71-80. [CrossRef]

22. Giordana, M.F.; Alvarez-Armas, I.; Armas, A. On the Cyclic Softening Mechanisms of Reduced Activity Ferritic/Martensitic Steels. Steel Res. Int. 2012, 83, 594-599. [CrossRef]

23. Landon, P.R.; Caligiuri, R.D.; Duletsky, P.S. The influence of the M23 (C,N)6 compound on the mechanical properties of type 422 stainless steel. Metall. Trans. A 1983, 14, 1395-1408. [CrossRef]

24. Hemmati, I.; Ocelík, V.; De Hosson, J.T.M. Microstructural characterization of AISI 431 martensitic stainless steel laser-deposited coatings. J. Mater. Sci. 2011, 46, 3405-3414. [CrossRef]

25. Huang, C.A.; Tu, G.C.; Yao, H.T.; Kuo, H.H. Characteristics of the rough-cut surface of quenched and tempered martensitic stainless steel using wire electrical discharge machining. Metall. Mater. Trans. A 2004, 35, 1351-1357. [CrossRef]

26. Venske, A.F.; de Castro, V.V.; da Costa, E.M.; dos Santos, C.A. Sliding Wear Behavior of an AISI 440B Martensitic Stainless Steel Lubricated with Biodiesel and Diesel-Biodiesel Blends. J. Mater. Eng. Perform. 2018, 27, 5427-5437. [CrossRef]

27. Hasan, S.; Thamizhmanii, S. Tool flank wear analyses on AISI 440 C martensitic stainless steel by turning. Int. J. Mater. Form. 2010, 3, 427-430. [CrossRef]

28. Aghaie-Khafri, M.; Adhami, F. Hot deformation of 15-5 PH stainless steel. Mater. Sci. Eng. A 2010, 527, 1052-1057. [CrossRef]

29. Zukerman, I.; Raveh, A.; Kalman, H.; Klemberg-Sapieha, J.E.; Martinu, L. Thermal stability and wear resistance of hard TiN/TiCN coatings on plasma nitrided PH15-5 steel. Wear 2007, 263, 1249-1252. [CrossRef]

30. Yu, W.-T.; Li, J.; Shi, C.-B.; Zhu, Q.-T. Effect of Spheroidizing Annealing on Microstructure and Mechanical Properties of High-Carbon Martensitic Stainless Steel 8Cr13MoV. J. Mater. Eng. Perform. 2017, 26, 478-487. [CrossRef]

31. Rafi, H.K.; Starr, T.L.; Stucker, B.E. A comparison of the tensile, fatigue, and fracture behavior of Ti-6Al-4V and 15-5 PH stainless steel parts made by selective laser melting. Int. J. Adv. Manuf. Technol. 2013, 69, 1299-1309. [CrossRef]

32. Mortezaei, S.; Arabi, H.; Seyedein, H.; Momeny, A.; Soltanalinezhad, M. Investigation on Microstructure Evolution of a SemiAustenitic Stainless Steel Through Hot Deformation TT. IUST 2020, 17, 60-69. [CrossRef]

33. Azizpour, A.; Hahn, R.; Klimashin, F.F.; Wojcik, T.; Poursaeidi, E.; Mayrhofer, P.H. Deformation and Cracking Mechanism in CrN/TiN Multilayer Coatings. Coatings 2019, 9, 363. [CrossRef]

34. Murayama, M.; Hono, K.; Katayama, Y. Microstructural evolution in a 17-4 PH stainless steel after aging at $400{ }^{\circ} \mathrm{C}$. Metall. Mater. Trans. A 1999, 30, 345-353. [CrossRef]

35. Reddy, V.V.; Kumar, A.; Valli, P.M.; Reddy, C.S. Influence of surfactant and graphite powder concentration on electrical discharge machining of PH17-4 stainless steel. J. Braz. Soc. Mech. Sci. Eng. 2015, 37, 641-655. [CrossRef] 
36. He, J.; Chen, L.; Tao, X.; Antonov, S.; Zhong, Y.; Su, Y. Hydrogen embrittlement behavior of 13Cr-5Ni-2Mo supermartensitic stainless steel. Corros. Sci. 2020, 176, 109046. [CrossRef]

37. An, G.; Liu, R.; Yin, G. Fatigue Limit of Custom 465 with Surface Strengthening Treatment. Materials 2020, 13, 238. [CrossRef] [PubMed]

38. Dennies, D.P. Proposed Theory for the Hydrogen Embrittlement Resistance of Martensitic Precipitation Age-Hardening Stainless Steels such as Custom 455. J. Fail. Anal. Prev. 2013, 13, 433-436. [CrossRef]

39. Ma, X.; Wang, L.; Subramanian, S.V.; Liu, C. Studies on Nb Microalloying of $13 \mathrm{Cr}$ Super Martensitic Stainless Steel. Metall. Mater. Trans. A 2012, 43, 4475-4486. [CrossRef]

40. Zhang, Y.; Yin, Y.; Li, D.; Ma, P.; Liu, Q.; Yuan, X.; Li, S. Temperature Dependent Phase Transformation Kinetics of Reverted Austenite during Tempering in 13Cr Supermartensitic Stainless Steel. Materials 2019, 9, 1203. [CrossRef]

41. De Oliveira, M.P.; Calderón-Hernández, J.W.; Magnabosco, R.; Hincapie-Ladino, D.; Alonso-Falleiros, N. Effect of Niobium on Phase Transformations, Mechanical Properties and Corrosion of Supermartensitic Stainless Steel. J. Mater. Eng. Perform. 2017, 26, 1664-1672. [CrossRef]

42. Finkler, H.; Schirra, M. Transformation behaviour of the high temperature martensitic steels with $8-14 \%$ chromium. Steel Res. 1996, 67, 328-342. [CrossRef]

43. Zhang, Y.; Zhang, C.; Yuan, X.; Li, D.; Yin, Y.; Li, S. Microstructure Evolution and Orientation Relationship of Reverted Austenite in 13Cr Supermartensitic Stainless Steel During the Tempering Process. Materials 2019, 12, 589. [CrossRef] [PubMed]

44. Zou, D.; Liu, R.; Li, J.; Zhang, W.; Wang, D.; Han, Y. Corrosion Resistance and Semiconducting Properties of Passive Films Formed on 00Cr13Ni5Mo2 Supermartensitic Stainless Steel in Cl- Environment. J. Iron Steel Res. Int. 2014, 21, 630-636. [CrossRef]

45. Fu, X.; Bai, P.; Yang, J. Hot Deformation Characteristics of $18 \mathrm{Cr}-5 \mathrm{Ni}-4 \mathrm{Cu}-\mathrm{N}$ Stainless Steel Using Constitutive Equation and Processing Map. Metals 2020, 10, 82. [CrossRef]

46. Roberts, W.N. Development of needles and sutures for microsurgery. J. Biomed. Mater. Res. 1975, 9, 399-405. [CrossRef] [PubMed]

47. Kevanlo, E.; Ebrahimi, G.R.; Sani, S.A.A.; Momeni, A. Dynamic recrystallization kinetics of AISI 403 stainless steel using hot compression test. Iran. J. Mater. Form. 2014, 1, 32-43. [CrossRef]

48. Mirzaee, M.; Keshmiri, H.; Ebrahimi, G.R.; Momeni, A. Dynamic recrystallization and precipitation in low carbon low alloy steel 26NiCrMoV 14-5. Mater. Sci. Eng. A 2012, 551, 25-31. [CrossRef]

49. Yan, T.; Yu, E.; Zhao, Y. Constitutive modeling for flow stress of 55SiMnMo bainite steel at hot working conditions. Mater. Des. 2013, 50, 574-580. [CrossRef]

50. Dehghan, H.; Abbasi, S.M.; Momeni, A.; Karimi Taheri, A. On the constitutive modeling and microstructural evolution of hot compressed A286 iron-base superalloy. J. Alloys Compd. 2013, 564, 13-19. [CrossRef]

51. Momeni, A.; Dehghani, K.; Heidari, M.; Vaseghi, M. Modeling the Flow Curve of AISI 410 Martensitic Stainless Steel. J. Mater. Eng. Perform. 2012, 21, 2238-2243. [CrossRef]

52. Momeni, A.; Dehghani, K.; Ebrahimi, G.R. Modeling the initiation of dynamic recrystallization using a dynamic recovery model. J. Alloys Compd. 2011, 509, 9387-9393. [CrossRef]

53. Bang, W.; Lee, C.S.; Chang, Y.W. Finite element analysis of hot forging with flow softening by dynamic recrystallization. J. Mater. Process. Technol. 2003, 134, 153-158. [CrossRef]

54. Huang, J.; $\mathrm{Xu}, \mathrm{Z}$. Evolution mechanism of grain refinement based on dynamic recrystallization in multiaxially forged austenite. Mater. Lett. 2006, 60, 1854-1858. [CrossRef]

55. Yang, Y.; Yan, Q.; Ge, C. Hot Deformation Behavior of Modified CNS- II F/M Steel. J. Iron Steel Res. Int. 2012, 19, 60-65. [CrossRef]

56. Li, C.; Liu, Y.; Tan, Y.; Zhao, F. Hot Deformation Behavior and Constitutive Modeling of H13-Mod Steel. Metals 2018, 8, 846. [CrossRef]

57. Xu, Y.; Liu, J.S.; Jiao, Y.X. Hot Deformation Behavior and Dynamic Recrystallization Characteristics of 12Cr Ultra-Super-Critical Rotor Steel. Met. Mater. Int. 2019, 25, 823-837. [CrossRef]

58. Murillo-Marrodán, A.; Puchi-Cabrera, E.S.; García, E.; Dubar, M.; Cortés, F.; Dubar, L. An Incremental Physically-Based Model of P91 Steel Flow Behaviour for the Numerical Analysis of Hot-Working Processes. Metals 2018, 8, 269. [CrossRef]

59. Wang, R.; Wang, M.; Li, Z.; Lu, C. Physics-based Constitutive Model for the Hot Deformation of 2Cr11Mo1VNbN Martensitic Stainless Steel. J. Mater. Eng. Perform. 2018, 27, 4932-4940. [CrossRef]

60. Safara, N.; Engberg, G.; Ågren, J. Modeling Microstructure Evolution in a Martensitic Stainless Steel Subjected to Hot Working Using a Physically Based Model. Metall. Mater. Trans. A 2019, 50, 1480-1488. [CrossRef]

61. Ren, F.; Chen, F.; Chen, J.; Tang, X. Hot deformation behavior and processing maps of AISI 420 martensitic stainless steel. J. Manuf. Process. 2018, 31, 640-649. [CrossRef]

62. Kishor, B.; Chaudhari, G.P.; Nath, S.K. Hot Deformation Characteristics of $13 \mathrm{Cr}-4 \mathrm{Ni}$ Stainless Steel Using Constitutive Equation and Processing Map. J. Mater. Eng. Perform. 2016, 25, 2651-2660. [CrossRef]

63. Taylor, T.; Danks, S.; Fourlaris, G. Dynamic Tensile Testing of Ultrahigh Strength Hot Stamped Martensitic Steels. Steel Res. Int. 2017, 88, 1600144. [CrossRef]

64. Burke, J.E.; Turnbull, D. Recrystallization and grain growth. Prog. Met. Phys. 1952, 3, 220-292. [CrossRef]

65. Doherty, R.D.; Hughes, D.A.; Humphreys, F.J.; Jonas, J.J.; Jensen, D.J.; Kassner, M.E.; King, W.E.; McNelley, T.R.; McQueen, H.J.; Rollett, A.D. Current issues in recrystallization: A review. Mater. Sci. Eng. A 1997, 238, 219-274. [CrossRef] 
66. Seifert, M.; Siebert, S.; Huth, S.; Theisen, W.; Berns, H. New Developments in Martensitic Stainless Steels Containing C + N. Steel Res. Int. 2015, 86, 1508-1516. [CrossRef]

67. Sakai, T.; Belyakov, A.; Kaibyshev, R.; Miura, H.; Jonas, J.J. Dynamic and post-dynamic recrystallization under hot, cold and severe plastic deformation conditions. Prog. Mater. Sci. 2014, 60, 130-207. [CrossRef]

68. Miura, H.; Sakai, T.; Belyakov, A.; Gottstein, G.; Crumbach, M.; Verhasselt, J. Static recrystallization of SiO2-particle containing $\{011\}<100>$ copper single crystals. Acta Mater. 2003, 51, 1507-1515. [CrossRef]

69. Humphreys, F.J.; Hatherly, M.B.T.-R. (Eds.) Appendix 1 Texture, 2nd ed.; Elsevier: Oxford, UK, 2004; pp. 527-540. ISBN 978-0-08-044164-1.

70. Ahlborn, H.; Hornbogen, E.; Köster, U. Recrystallisation mechanism and annealing texture in aluminium-copper alloys. J. Mater. Sci. 1969, 4, 944-950. [CrossRef]

71. Zeng, Z.; Chen, L.; Zhu, F.; Liu, X. Dynamic Recrystallization Behavior of a Heat-resistant Martensitic Stainless Steel 403Nb during Hot Deformation. J. Mater. Sci. Technol. 2011, 27, 913-919. [CrossRef]

72. Fang, Y.; Chen, X.; Madigan, B.; Cao, H.; Konovalov, S. Effects of strain rate on the hot deformation behavior and dynamic recrystallization in China low activation martensitic steel. Fusion Eng. Des. 2016, 103, 21-30. [CrossRef]

73. Ebrahimi, G.R.; Momeni, A.; Jahazi, M.; Bocher, P. Dynamic Recrystallization and Precipitation in 13Cr Super-Martensitic Stainless Steels. Metall. Mater. Trans. A 2014, 45, 2219-2231. [CrossRef]

74. Shafiei, E.; Dehghani, K. Prediction of Single-Peak Flow Stress Curves at High Temperatures Using a New Logarithmic-Power Function. J. Mater. Eng. Perform. 2016, 25, 4024-4035. [CrossRef]

75. Ahmadabadi, R.M.; Naderi, M.; Mohandesi, J.A.; Cabrera, J.M. Dynamic Recrystallization Behavior of AISI 422 Stainless Steel During Hot Deformation Processes. J. Mater. Eng. Perform. 2018, 27, 560-571. [CrossRef]

76. Samantaray, D.; Phaniraj, C.; Mandal, S.; Bhaduri, A.K. Strain dependent rate equation to predict elevated temperature flow behavior of modified 9Cr-1Mo (P91) steel. Mater. Sci. Eng. A 2011, 528, 1071-1077. [CrossRef]

77. Jonas, J.J.; Sellars, C.M.; Tegart, W.J.M. Strength and structure under hot-working conditions. Metall. Rev. 1969, 14, 1-24. [CrossRef]

78. Al-Samman, T.; Gottstein, G. Dynamic recrystallization during high temperature deformation of magnesium. Mater. Sci. Eng. A 2008, 490, 411-420. [CrossRef]

79. Ion, S.E.; Humphreys, F.J.; White, S.H. Dynamic recrystallisation and the development of microstructure during the high temperature deformation of magnesium. Acta Metall. 1982, 30, 1909-1919. [CrossRef]

80. Nesterenko, V.F.; Meyers, M.A.; LaSalvia, J.C.; Bondar, M.P.; Chen, Y.J.; Lukyanov, Y.L. Shear localization and recrystallization in high-strain, high-strain-rate deformation of tantalum. Mater. Sci. Eng. A 1997, 229, 23-41. [CrossRef]

81. Solberg, J.K.; McQueen, H.J.; Ryum, N.; Nes, E. Influence of ultra-high strains at elevated temperatures on the microstructure of aluminium. Part I. Philos. Mag. A 1989, 60, 447-471. [CrossRef]

82. Hales, S.J.; McNelley, T.R.; McQueen, H.J. Recrystallization and superplasticity at $300{ }^{\circ} \mathrm{C}$ in an aluminum-magnesium alloy. Metall. Trans. A 1991, 22, 1037-1047. [CrossRef]

83. Ponge, D.; Gottstein, G. Necklace formation during dynamic recrystallization: Mechanisms and impact on flow behavior. Acta Mater. 1998, 46, 69-80. [CrossRef]

84. Sakai, T.; Jonas, J.J. Plastic Deformation: Role of Recovery and Recrystallization. In Encyclopedia of Materials: Science and Technology; Buschow, K.H.J., Cahn, R.W., Flemings, M.C., Ilschner, B., Kramer, E.J., Mahajan, S., Veyssière, P., Eds.; Elsevier: Oxford, UK, 2001; pp. 7079-7084. ISBN 978-0-08-043152-9.

85. Qing, L.; Xiaoxu, H.; Mei, Y.; Jinfeng, Y. On deformation-induced continuous recrystallization in a superplastic $\mathrm{Al} \mathrm{Li} \mathrm{Cu} \mathrm{Mg} \mathrm{Zr}$ alloy. Acta Metall. Mater. 1992, 40, 1753-1762. [CrossRef]

86. Lv, J.; Zheng, J.-H.; Yardley, V.A.; Shi, Z.; Lin, J. A Review of Microstructural Evolution and Modelling of Aluminium Alloys under Hot Forming Conditions. Metals 2020, 10, 1516. [CrossRef]

87. Tsuji, N.; Matsubara, Y.; Saito, Y. Dynamic recrystallization of ferrite in interstitial free steel. Scr. Mater. 1997, 37, 477-484. [CrossRef]

88. Gourdet, S.; Montheillet, F. An experimental study of the recrystallization mechanism during hot deformation of aluminium. Mater. Sci. Eng. A 2000, 283, 274-288. [CrossRef]

89. Sitdikov, O.; Sakai, T.; Miura, H.; Hama, C. Temperature effect on fine-grained structure formation in high-strength $\mathrm{Al}$ alloy 7475 during hot severe deformation. Mater. Sci. Eng. A 2009, 516, 180-188. [CrossRef]

90. Sitdikov, O.; Kaibyshev, R. Dynamic Recrystallization in Pure Magnesium. Mater. Trans. 2001, 42, 1928-1937. [CrossRef]

91. Ito, Y.; Horita, Z. Microstructural evolution in pure aluminum processed by high-pressure torsion. Mater. Sci. Eng. A 2009, 503, 32-36. [CrossRef]

92. Kaibyshev, R.; Sitdikov, O.; Goloborodko, A.; Sakai, T. Grain refinement in as-cast 7475 aluminum alloy under hot deformation. Mater. Sci. Eng. A 2003, 344, 348-356. [CrossRef]

93. Mazurina, I.; Sakai, T.; Miura, H.; Sitdikov, O.; Kaibyshev, R. Effect of deformation temperature on microstructure evolution in aluminum alloy 2219 during hot ECAP. Mater. Sci. Eng. A 2008, 486, 662-671. [CrossRef]

94. Bolli, E.; Fava, A.; Ferro, P.; Kaciulis, S.; Mezzi, A.; Montanari, R.; Varone, A. Cr Segregation and Impact Fracture in a Martensitic Stainless Steel. Coatings 2020, 10, 843. [CrossRef] 
95. Kassner, M.E.; Barrabes, S.R. New developments in geometric dynamic recrystallization. Mater. Sci. Eng. A 2005, 410-411, 152-155. [CrossRef]

96. Mironov, S.; Murzinova, M.; Zherebtsov, S.; Salishchev, G.A.; Semiatin, S.L. Microstructure evolution during warm working of Ti-6Al-4V with a colony- $\alpha$ microstructure. Acta Mater. 2009, 57, 2470-2481. [CrossRef]

97. Pettersen, T.; Holmedal, B.; Nes, E. Microstructure development during hot deformation of aluminum to large strains. Metall. Mater. Trans. A 2003, 34, 2737-2744. [CrossRef]

98. Blum, W.; Zhu, Q.; Merkel, R.; McQueen, H.J. Geometric dynamic recrystallization in hot torsion of Al-5Mg-0.6Mn (AA5083). Mater. Sci. Eng. A 1996, 205, 23-30. [CrossRef]

99. Miura, H.; Aoyama, H.; Sakai, T. Effect of Grain-Boundary Misorientation on Dynamic Recrystallization of Cu-Si Bicrystals. J. Jpn. Inst. Met. 1994, 58, 267-275. [CrossRef]

100. Wang, Z.; Wang, X.; Zhu, Z. Characterization of high-temperature deformation behavior and processing map of TB17 titanium alloy. J. Alloys Compd. 2017, 692, 149-154. [CrossRef]

101. Li, X.; Hou, L.; Wei, Y.; Wei, Z. Constitutive Equation and Hot Processing Map of a Nitrogen-Bearing Martensitic Stainless Steel. Metals 2020, 10, 1502. [CrossRef]

102. Großeiber, S.; Ilie, S.; Poletti, C.; Harrer, B.; Degischer, H.P. Influence of Strain Rate on Hot Ductility of a V-Microalloyed Steel Slab. Steel Res. Int. 2012, 83, 445-455. [CrossRef]

103. Lin, Y.C.; Liu, G. Effects of strain on the workability of a high strength low alloy steel in hot compression. Mater. Sci. Eng. A 2009, 523, 139-144. [CrossRef]

104. Prasad, Y.V.R.K.; Seshacharyulu, T. Modelling of hot deformation for microstructural control. Int. Mater. Rev. 1998, 43, $243-258$. [CrossRef]

105. Huang, D.; Feng, W. Hot Deformation Characteristics and Processing Map of FV520B Martensitic Precipitation-Hardened Stainless Steel. J. Mater. Eng. Perform. 2019, 28, 2281-2291. [CrossRef]

106. Dehghan-Manshadi, A.; Barnett, M.R.; Hodgson, P.D. Recrystallization in AISI 304 austenitic stainless steel during and after hot deformation. Mater. Sci. Eng. A 2008, 485, 664-672. [CrossRef]

107. Bricknell, R.H.; Edington, J.W. Textures in a superplastic Al-6Cu-0.3Zr alloy. Acta Metall. 1979, 27, 1303-1311. [CrossRef]

108. Nes, E. Hot deformation behaviour of particle-stabilized structures in Zr-bearing Al alloys. Met. Sci. 1979, 13, 211-215. [CrossRef]

109. McQueen, H.J.; Solberg, J.K.; Ryum, N.; Nes, E. Evolution of flow stress in aluminium during ultra-high straining at elevated temperatures. Part II. Philos. Mag. A 1989, 60, 473-485. [CrossRef]

110. McQueen, H.J.; Ryan, N.D.; Konopleva, E.V.; Xia, X. Formation and application of grain boundary serrations. Can. Metall. Q. 1995, 34, 219-229. [CrossRef]

111. Zhu, Y.T.; Langdon, T.G. The fundamentals of nanostructured materials processed by severe plastic deformation. JOM 2004, 56, 58-63. [CrossRef]

112. Gourdet, S.; Montheillet, F. A model of continuous dynamic recrystallization. Acta Mater. 2003, 51, 2685-2699. [CrossRef]

113. McNelley, T.R.; Swisher, D.L.; Pérez-Prado, M.T. Deformation bands and the formation of grain boundaries in a superplastic aluminum alloy. Metall. Mater. Trans. A 2002, 33, 279-290. [CrossRef]

114. Mehtonen, S.V.; Karjalainen, L.P.; Porter, D.A. Hot deformation behavior and microstructure evolution of a stabilized high-Cr ferritic stainless steel. Mater. Sci. Eng. A 2013, 571, 1-12. [CrossRef]

115. Gao, F.; Liu, Z.; Misra, R.D.K.; Liu, H.; Yu, F. Constitutive modeling and dynamic softening mechanism during hot deformation of an ultra-pure $17 \% \mathrm{Cr}$ ferritic stainless steel stabilized with Nb. Met. Mater. Int. 2014, 20, 939-951. [CrossRef]

116. Huang, K.; Logé, R.E. A review of dynamic recrystallization phenomena in metallic materials. Mater. Des. 2016, 111, 548-574. [CrossRef]

117. Lin, J.; Liu, Y.; Farrugia, D.C.J.; Zhou, M. Development of dislocation-based unified material model for simulating microstructure evolution in multipass hot rolling. Philos. Mag. 2005, 85, 1967-1987. [CrossRef]

118. Raabe, D. Recovery and Recrystallization: Phenomena, Physics, Models, Simulation, 5th ed.; Laughlin, D.E., Hono, K.B.T.-P.M., Eds.; Elsevier: Oxford, UK, 2014; pp. 2291-2397. ISBN 978-0-444-53770-6.

119. Yamagata, H. Dynamic recrystallization of single-crystalline aluminum during compression tests. Scr. Metall. Mater. 1992, 27, 727-732. [CrossRef]

120. Ebrahimi, G.R.; Keshmiri, H.; Maldad, A.R.; Momeni, A. Dynamic Recrystallization Behavior of $13 \%$ Cr Martensitic Stainless Steel under Hot Working Condition. J. Mater. Sci. Technol. 2012, 28, 467-473. [CrossRef]

121. Ebrahimi, G.R.; Keshmiri, H.; Momeni, A.; Mazinani, M. Dynamic recrystallization behavior of a superaustenitic stainless steel containing 16\%Cr and 25\%Ni. Mater. Sci. Eng. A 2011, 528, 7488-7493. [CrossRef]

122. Momeni, A.; Dehghani, K.; Keshmiri, H.; Ebrahimi, G.R. Hot deformation behavior and microstructural evolution of a superaustenitic stainless steel. Mater. Sci. Eng. A 2010, 527, 1605-1611. [CrossRef]

123. Ryan, N.D.; McQueen, H.J. Flow stress, dynamic restoration, strain hardening and ductility in hot working of 316 steel. J. Mater. Process. Technol. 1990, 21, 177-199. [CrossRef]

124. El Wahabi, M.; Gavard, L.; Montheillet, F.; Cabrera, J.M.; Prado, J.M. Effect of initial grain size on dynamic recrystallization in high purity austenitic stainless steels. Acta Mater. 2005, 53, 4605-4612. [CrossRef]

125. Huo, J.; Wu, H.; Yang, J.; Sun, W.; Li, G.; Sun, X. Multi-directional coupling dynamic characteristics analysis of TBM cutterhead system based on tunnelling field test. J. Mech. Sci. Technol. 2015, 29, 3043-3058. [CrossRef] 
126. Momeni, A.; Dehghani, K. Prediction of dynamic recrystallization kinetics and grain size for 410 martensitic stainless steel during hot deformation. Met. Mater. Int. 2010, 16, 843-849. [CrossRef]

127. Cai, X.; Hu, X.-Q.; Zheng, L.-G.; Li, D.-Z. Hot Deformation Behavior and Processing Maps of 0.3C-15Cr-1Mo-0.5N High Nitrogen Martensitic Stainless Steel. Acta Metall. Sin. 2020, 33, 693-704. [CrossRef]

128. Mcqueen, H.J.; Jonas, J.J. Recent advances in hot working: Fundamental dynamic softening mechanisms. J. Appl. Metalwork. 1984, 3, 233-241. [CrossRef]

129. McQueen, H.J. The production and utility of recovered dislocation substructures. Metall. Trans. A 1977, 8, 807-824. [CrossRef]

130. Song, R.; Ponge, D.; Raabe, D.; Kaspar, R. Microstructure and crystallographic texture of an ultrafine grained C-Mn steel and their evolution during warm deformation and annealing. Acta Mater. 2005, 53, 845-858. [CrossRef]

131. Storojeva, L.; Ponge, D.; Kaspar, R.; Raabe, D. Development of microstructure and texture of medium carbon steel during heavy warm deformation. Acta Mater. 2004, 52, 2209-2220. [CrossRef]

132. Dehghan-Manshadi, A.; Hodgson, P.D. Effect of $\delta$-ferrite co-existence on hot deformation and recrystallization of austenite. $J$. Mater. Sci. 2008, 43, 6272-6277. [CrossRef]

133. Tsuzaki, K.; Huang, X.; Maki, T. Mechanism of dynamic continuous recrystallization during superplastic deformation in a microduplex stainless steel. Acta Mater. 1996, 44, 4491-4499. [CrossRef]

134. Cizek, P. The microstructure evolution and softening processes during high-temperature deformation of a $21 \mathrm{Cr}-10 \mathrm{Ni}-3 \mathrm{Mo}$ duplex stainless steel. Acta Mater. 2016, 106, 129-143. [CrossRef]

135. Belyakov, A.; Miura, H.; Sakai, T. Dynamic recrystallization in ultra fine-grained 304 stainless steel. Scr. Mater. 2000, 43, 21-26. [CrossRef]

136. Mcqueen, H.J.; Jonas, J.J. Recovery and Recrystallization during High Temperature Deformation. In Plastic Deformation of Materials; Elsevier: Amsterdam, The Netherlands, 1975; Volume 6, pp. 393-493. ISBN 0161-9160.

137. Sakai, T. Dynamic recrystallization microstructures under hot working conditions. J. Mater. Process. Technol. 1995, 53, 349-361. [CrossRef]

138. Shaikh, A.; Churyumov, A.; Pozdniakov, A.; Churyumova, T. Simulation of the Hot Deformation and Fracture Behavior of Reduced Activation Ferritic/Martensitic 13CrMoNbV Steel. Appl. Sci. 2020, 10, 530. [CrossRef]

139. Opěla, P.; Schindler, I.; Kawulok, P.; Kawulok, R.; Rusz, S.; Navrátil, H.; Jurča, R. Correlation among the Power Dissipation Efficiency, Flow Stress Course, and Activation Energy Evolution in Cr-Mo Low-Alloyed Steel. Materials 2020, 13, 3480. [CrossRef] [PubMed]

140. Ma, X.P.; Wang, L.J.; Liu, C.M.; Subramanian, S.V. Microstructure and properties of 13Cr5Ni1Mo0.025Nb0.09V0.06N super martensitic stainless steel. Mater. Sci. Eng. A 2012, 539, 271-279. [CrossRef]

141. Chen, L.; Zeng, Z.; Zhao, Y.; Zhu, F.; Liu, X. Microstructures and High-Temperature Mechanical Properties of a Martensitic Heat-Resistant Stainless Steel 403Nb Processed by Thermo-Mechanical Treatment. Metall. Mater. Trans. A 2014, 45, $1498-1507$. [CrossRef]

142. Hollner, S.; Piozin, E.; Mayr, P.; Caës, C.; Tournié, I.; Pineau, A.; Fournier, B. Characterization of a boron alloyed 9Cr3W3CoVNbBN steel and further improvement of its high-temperature mechanical properties by thermomechanical treatments. J. Nucl. Mater. 2013, 441, 15-23. [CrossRef]

143. Hollner, S.; Fournier, B.; Le Pendu, J.; Cozzika, T.; Tournié, I.; Brachet, J.-C.; Pineau, A. High-temperature mechanical properties improvement on modified 9Cr-1Mo martensitic steel through thermomechanical treatments. J. Nucl. Mater. 2010, 405, 101-108. [CrossRef]

144. Klueh, R.L.; Hashimoto, N.; Maziasz, P.J. New nano-particle-strengthened ferritic/martensitic steels by conventional thermomechanical treatment. J. Nucl. Mater. 2007, 367-370, 48-53. [CrossRef]

145. Klueh, R.L.; Hashimoto, N.; Maziasz, P.J. Development of new nano-particle-strengthened martensitic steels. Scr. Mater. 2005, 53, 275-280. [CrossRef]

146. Taneike, M.; Abe, F.; Sawada, K. Creep-strengthening of steel at high temperatures using nano-sized carbonitride dispersions. Nature 2003, 424, 294-296. [CrossRef] [PubMed]

147. Rojas, D.; Garcia, J.; Prat, O.; Agudo, L.; Carrasco, C.; Sauthoff, G.; Kaysser-Pyzalla, A.R. Effect of processing parameters on the evolution of dislocation density and sub-grain size of a $12 \% \mathrm{Cr}$ heat resistant steel during creep at $650{ }^{\circ} \mathrm{C}$. Mater. Sci. Eng. A 2011, 528, 1372-1381. [CrossRef]

148. Hald, J. Microstructure and long-term creep properties of 9-12\% Cr steels. Int. J. Press. Vessel. Pip. 2008, 85, 30-37. [CrossRef]

149. Hu, Z.; He, D.; Mo, F. Carbides Evolution in 12Cr Martensitic Heat-resistant Steel with Life Depletion for Long-term Service. J. Iron Steel Res. Int. 2015, 22, 250-255. [CrossRef]

150. Hänninen, H.; Romu, J.; Ilola, R.; Tervo, J.; Laitinen, A. Effects of processing and manufacturing of high nitrogen-containing stainless steels on their mechanical, corrosion and wear properties. J. Mater. Process. Technol. 2001, 117, 424-430. [CrossRef]

151. Vedani, M.; Dellasega, D.; Mannuccii, A. Characterization of Grain-boundary Precipitates after Hot-ductility Tests of Microalloyed Steels. ISIJ Int. 2009, 49, 446-452. [CrossRef]

152. Ohadi, D.; Parsa, M.H.; Mirzadeh, H. Development of dynamic recrystallization maps based on the initial grain size. Mater. Sci. Eng. A 2013, 565, 90-95. [CrossRef]

153. Zhang, S.; Wang, P.; Li, D.; Li, Y. In situ investigation on the deformation-induced phase transformation of metastable austenite in $\mathrm{Fe}-13 \%$ Cr-4\% Ni martensitic stainless steel. Mater. Sci. Eng. A 2015, 635, 129-132. [CrossRef] 
154. Zou, D.; Liu, X.; Han, Y.; Zhang, W.; Li, J.; Wu, K. Influence of Heat Treatment Temperature on Microstructure and Property of 00Crl3Ni5Mo2 Supermartensitic Stainless Steel. J. Iron Steel Res. Int. 2014, 21, 364-368. [CrossRef]

155. Jia, N.; Cong, Z.H.; Sun, X.; Cheng, S.; Nie, Z.H.; Ren, Y.; Liaw, P.K.; Wang, Y.D. An in situ high-energy X-ray diffraction study of micromechanical behavior of multiple phases in advanced high-strength steels. Acta Mater. 2009, 57, 3965-3977. [CrossRef]

156. Fu, B.; Yang, W.Y.; Wang, Y.D.; Li, L.F.; Sun, Z.Q.; Ren, Y. Micromechanical behavior of TRIP-assisted multiphase steels studied with in situ high-energy X-ray diffraction. Acta Mater. 2014, 76, 342-354. [CrossRef]

157. Momeni, A.; Arabi, H.; Rezaei, A.; Badri, H.; Abbasi, S.M. Hot deformation behavior of austenite in HSLA-100 microalloyed steel. Mater. Sci. Eng. A 2011, 528, 2158-2163. [CrossRef]

158. Shabashov, V.A.; Korshunov, L.G.; Zamatovskii, A.E.; Litvinov, A.V.; Sagaradze, V.V.; Kositsyna, I.I. Deformation-induced dissolution of carbides of the $\mathrm{Me}(\mathrm{V}, \mathrm{Mo})-\mathrm{C}$ Type in high-manganese steels upon the friction effect. Phys. Met. Metallogr. 2012, 113, 914-921. [CrossRef]

159. Srivatsa, K.; Srinivas, P.; Balachandran, G.; Balasubramanian, V. Improvement of impact toughness by modified hot working and heat treatment in 13\%Cr martensitic stainless steel. Mater. Sci. Eng. A 2016, 677, 240-251. [CrossRef]

160. Liu, Y.; Ye, S.L.; An, B.; Wang, Y.G.; Li, Y.J.; Zhang, L.C.; Wang, W.M. Effects of mechanical compression and autoclave treatment on the backbone clusters in the Al86Ni9La5 amorphous alloy. J. Alloys Compd. 2014, 587, 59-65. [CrossRef]

161. Momeni, A.; Dehghani, K. Characterization of hot deformation behavior of 410 martensitic stainless steel using constitutive equations and processing maps. Mater. Sci. Eng. A 2010, 527, 5467-5473. [CrossRef]

162. Zhou, P.; Ma, Q.-X. Dynamic Recrystallization Behavior and Processing Map Development of 25CrMo4 Mirror Plate Steel During Hot Deformation. Acta Metall. Sin. 2017, 30, 907-920. [CrossRef]

163. Zhao, C.; Zhang, J.; Yang, B.; Li, Y.F.; Huang, J.F.; Lian, Y. Hot Deformation Characteristics and Processing Map of 1Cr12Ni2Mo2WVNb Martensitic Stainless Steel. Steel Res. Int. 2020, 91, 2000020. [CrossRef] 